\title{
Ghrelin Treatment Induces Rapid and Delayed Increments of Food Intake: A Heuristic Model to Explain Ghrelin's Orexigenic Effects
}

\section{Maria Paula Cornejo}

Multidisciplinary Institute of Cell Biology (IMBICE) - Argentine Research Council (CONICET), Scientific Research Commission (CIC-PBA), National University of La Plata (UNLP)

\section{Raphael Denis}

Université de Paris, Unité de Biologie Fonctionnelle et Adaptive (BFA), UNR 2851, CNRS, F-75013 Paris,

France

\section{Guadalupe Garcia Romero}

Multidisciplinary Institute of Cell Biology (IMBICE) - Argentine Research Council (CONICET), Scientific

Research Commission (CIC-PBA), National University of La Plata (UNLP)

\section{Gimena Fernandez}

Multidisciplinary Institute of Cell Biology (IMBICE) - Argentine Research Council (CONICET), Scientific

Research Commission (CIC-PBA), National University of La Plata (UNLP)

\section{Mirta Reynaldo}

Multidisciplinary Institute of Cell Biology (IMBICE) - Argentine Research Council (CONICET), Scientific Research Commission (CIC-PBA), National University of La Plata (UNLP)

\section{Serge Luquet}

Université de Paris, Unité de Biologie Fonctionnelle et Adaptative (BFA), UMR 2851, CNRS, F-75013 Paris,

France

\section{Mario Perello ( $\triangle$ mperello@imbice.gov.ar)}

Multidisciplinary Institute of Cell Biology (IMBICE) https://orcid.org/0000-0003-2114-6765

\section{Research Article}

Keywords: Ghrelin, arcuate, AgRP, delayed effect

Posted Date: June 2nd, 2021

DOI: https://doi.org/10.21203/rs.3.rs-538169/v1

License: (9) This work is licensed under a Creative Commons Attribution 4.0 International License. Read Full License 


\section{Abstract}

Ghrelin is a stomach-derived peptide hormone with salient roles in the regulation of energy balance and metabolism. Notably, ghrelin is recognized as the most powerful known circulating orexigenic hormone. Here, we systematically investigated the effects of ghrelin on energy homeostasis and found that ghrelin primarily induces a biphasic effect on food intake that has indirect consequences on energy expenditure and nutrient partitioning. We also found that ghrelin-induced biphasic effect on food intake requires the integrity of Agouti-related peptide/neuropeptide Y-producing neurons of the hypothalamic arcuate nucleus (ARH), which seem to display a long-lasting activation after a single systemic injection of ghrelin. Finally, we found that different autonomic, hormonal and metabolic satiation signals transiently counteract ghrelin-induced food intake. Based on our observations, we propose a heuristic model to describe how the orexigenic effect of ghrelin and the anorectic food intake-induced rebound sculpt a timely constrain feeding response to ghrelin.

\section{Introduction}

Ghrelin is an octanoylated peptide hormone synthesized in the stomach fundus that acts via the growth hormone secretagogue receptor (GHSR), which is mainly expressed in the brain. Ghrelin plays key roles regulating energy balance and metabolism [1]. The role of ghrelin becomes more evident in energy deficit conditions, such as calorie restriction or fasting, when plasma ghrelin levels increase and contribute to upregulate food seeking, food intake and hyperglycemic mechanisms [2,3]. In this regard, ghrelin is recognized as the most powerful known orexigenic hormone. In particular, systemically injected ghrelin potently ( 7-fold) and rapidly ( $0.25 \mathrm{~h}$ after injection) increases food intake in satiated fed mice [4-6]. Ghrelin also increases food intake in many other species, including humans [7]. The orexigenic effect of circulating ghrelin appears to mainly involve neurons of the hypothalamic arcuate nucleus (ARH) that synthesize the orexigenic neuropeptides agouti-related protein (AgRP) and neuropeptide Y (NPY), hereafter named $\mathrm{ARH} \mathrm{AgRP}^{\mathrm{ANPY}}$ neurons, which are critical regulators of feeding [8]. Indeed, optogenetic or chemogenetic activation of $A R H^{A g R P / N P Y}$ neurons potently increases food intake $[9,10]$, while its inhibition or ablation reduces food intake or even leads to aphagia [10-12]. ARH ${ }^{A g R P / N P Y}$ neurons express high levels of GHSR and rapidly sense elevations of plasma ghrelin [13]. Systemically injected ghrelin fails to induce food intake in mice with ablation of either the entire ARH or exclusively the ARH ${ }^{A g R P / N P Y}$ neurons $[4,12]$. Also, ghrelin increases food intake in mice with selective expression of GHSR in $A R H^{A g R P / N P Y}$ neurons [14], and fails to increase food intake in mice lacking GHSR in ARH AgRP/NPY neurons [15]. Besides food intake, some studies found that ghrelin also affects energy balance through the regulation of the respiratory exchange ratio (RER), locomotor activity or energy expenditure (EE). The RER represents the $\mathrm{CO}_{2}$ volume produced per $\mathrm{O}_{2}$ volume consumed and is an indirect measurement of the type of nutrients that are oxidized to obtain energy, with RER $=1$ for carbohydrate and RER $=0.7$ for lipid-based substrate utilization [16]. Early evidence showed that a single systemic injection of ghrelin in ad libitum fed mice increases the RER $\sim 1 \mathrm{~h}$ after treatment, suggesting that ghrelin favors carbohydrate oxidation over fat [17]. The putative effects of ghrelin on locomotor activity or EE are more controversial. 
Some studies found that systemically injected ghrelin induces a 2-fold increase of locomotor activity in mice within the $0-1 \mathrm{~h}$ post-treatment period [18-20] whereas other studies could not confirm such observation $[17,21]$. Similarly, a study reported that systemically injected ghrelin transiently decreases EE in mice in the $~ 0.5-1 \mathrm{~h}$ post-treatment period [22], whereas other studies reported that systemic or central administration of ghrelin does not affect EE in rodents $[17,23]$. Thus, the orexigenic effect of ghrelin and its neurobiological basis are well-established; in contrast, the degree to which ghrelin affects energy balance via the regulation of locomotor activity, EE or the RER remains more uncertain.

The potent orexigenic effect of ghrelin treatment supports the notion that this hormone (or ghrelinmimetic compounds) could be used to treat patients suffering loss of appetite or weight loss. However, it seems clear that many intricacies regarding the coordinated action of ghrelin in the modulation of energy balance are still unsolved. Thus, the current study was performed to comprehensively characterize the interplay among ghrelin's effects on energy homeostasis in mice. For this purpose, we first performed a systematic, dose-response and time-response analysis of the effects of ghrelin treatment on food intake, locomotor activity, EE and the RER in ad libitum fed or mice deprived of food during the measurements. Since our results indicated that ghrelin plays a major role as an orexigenic signal, we performed further studies aimed to better understand the effect of ghrelin on food intake over time as well as the endogenous factors that sculpt the shape of such effect. Based on our observations, we propose a heuristic model to explain ghrelin's effects on energy balance.

\section{Material And Methods}

2.1 Animals. Mice were generated in the animal facility of either the IMBICE, at La Plata, or the animal core facility "Buffon" of the Université de Paris/Institut Jacques Monod. Mice models included: 1) C57BL/6 wild-type (WT) mice, 2) NPY-GFP mice, which express green-fluorescent protein (GFP) under the control of the NPY promoter (Jackson Laboratory, Stock \#006417) [24], and 3) AgRP-DTR mice, which express the human diphtheria toxin receptor (DTR) under the control of Agrp gene regulatory elements [12]. ARH neurons-ablated mice were generated as previously described [4]. Briefly, 4-day-old WT mice were subcutaneously treated with $10-15 \mu$ of saline alone or containing monosodium glutamate (2.5 $\mathrm{mg} / \mathrm{g}$ body weight (BW)) giving ARH-intact or ARH-ablated mice, respectively. The ablation of the ARH was histologically confirmed, as described in the past [4]. ARH ${ }^{A g R P / N P Y}$ neurons-ablated mice were generated as previously described [12]. Briefly, AgRP-DTR mice were subcutaneously injected with $20 \mu \mathrm{l}$ of saline alone or containing diphtheria toxin ( $75 \mathrm{ng} /$ mouse) during the first week after birth giving control or $\mathrm{ARH}^{\mathrm{AgRP} / \mathrm{NPY}}$ neurons-ablated mice, respectively. The extent of the ablation of $\mathrm{ARH} \mathrm{AgRP}^{\mathrm{ANPY}}$ neurons was confirmed using neuroanatomical and behavioral assessments, as also described in the past $[12,25]$. Mice were maintained under controlled temperature $\left(21^{\circ} \mathrm{C}\right)$ and photoperiod (12-hour light/dark cycle from 6:00 $\mathrm{h}$ to 18:00 h) with regular chow and water available ad libitum, and used for experiments at adulthood (10-14 weeks old). At La Plata, chow was provided by Gepsa (Grupo Pilar) and provided $2.5 \mathrm{kcal} / \mathrm{g}$ energy (weight composition: carbohydrates $28.8 \%$, proteins $25.5 \%$, fat $3.6 \%$, fibers $27.4 \%$, minerals $8.1 \%$ and water $6.7 \%$ ). At Paris, chow was provided by SAFE and provided $3.438 \mathrm{kcal} / \mathrm{g}$ 
energy (weight composition: carbohydrates 55\%, proteins $19 \%$ and fat $5 \%$ ). All studies were carried out in strict accordance with the recommendations in the Guide for the Care and Use of Laboratory Animals of the National Research Council, USA [26] and the European Communities Council Directive (86/609/EEC). All experimentations received approval from the Institutional Animal Care and Use Committee of the IMBICE (ID 15-0132) and the Animal Care Committee of the Université de Paris (CEB 02-2017).

2.2 Drugs. Ghrelin (from Global Peptides, cat no. PI-G-03 or from Tocris, 1465/1) was dissolved in phosphate-buffered saline (PBS, pH 7.4), frozen and prepared fresh on experimental days. Ghrelin was intraperitoneally (IP) injected at 15,60 or $150 \mathrm{pmol} / \mathrm{g} \mathrm{BW}$, depending on the experiment. Monosodium glutamate (Sigma-Aldrich, cat no. G1626) was dissolved in saline [4]. Hyoscine butyl-bromide solution (Buscapina ${ }^{\circledR}$, Boehringer Ingelheim) was diluted in PBS to $1 \mathrm{mg} / \mathrm{mL}$ and IP injected at $6 \mathrm{mg} / \mathrm{Kg} \mathrm{BW}$, which was chosen based on previous reports [27]. Glucose (Biopack, cat no. 2000963808) and 2-deoxy-Dglucose (Sigma-Aldrich, cat no. D8375) were dissolved in distilled water and IP injected at $2.25 \mathrm{mg} / \mathrm{Kg}$ and $250 \mathrm{mg} / \mathrm{Kg} \mathrm{BW}$, respectively, based on previous reports [28]. Recombinant murine leptin (The National Hormone and Pituitary Program, USA) was dissolved in alkaline PBS (pH 8.25), prepared fresh on experimental days and IP injected at $0.1 \mathrm{mg} / \mathrm{Kg} \mathrm{BW}$, based on previous reports [29]. Cholecystokinin sulphated octapeptide (CCK-8S; Asp-Tyr( $\mathrm{SO}_{3} \mathrm{H}$ )-Met-Gly-Trp-Met-Asp-Phe-amide; American Peptide Company) was dissolved in sterile PBS, diluted to $2 \mu \mathrm{g} / \mathrm{mL}$ and IP administered at $5 \mathrm{mg} / \mathrm{Kg} \mathrm{BW}$ based on previous reports [30]. Melanotan II (MTII, Phoenix Pharmaceuticals, cat no. 043 - 23) was dissolved in PBS, prepared fresh on experimental days and intra-cerebroventricularly (ICV) injected at $0.5 \mu \mathrm{g} / \mathrm{mouse}$ based on previous reports [31]. Diphtheria toxin (List Biological Laboratories) was dissolved in saline and administered at $50 \mathrm{mg} / \mathrm{kg}$, based on previous reports [12].

2.3 Plasma ghrelin assessment. WT mice were IP injected with vehicle alone or containing ghrelin. Blood was collected from the facial vein at 15, 30, 45 and 60 min post-injection in tubes pre-treated with ethylenediaminetetraacetic acid ( $1 \mathrm{mg} / \mathrm{mL}$ final) and the protease inhibitor $\mathrm{p}$-hydroxy-mercuribenzoic acid ( $0.4 \mathrm{mM}$ final). Blood samples were centrifuged at $2655 \mathrm{~g}$ for $10 \mathrm{~min}$ at $4^{\circ} \mathrm{C}$. Plasma was separated, acidified with $1 \mathrm{M} \mathrm{HCl}\left(0.1 \mathrm{M}\right.$ final) to preserve ghrelin acylation and stored frozen at $-80^{\circ} \mathrm{C}$ until processing. Plasma ghrelin levels were assessed using an enzymatic immunoassay from Bertin Pharma (cat no. A05118), as reported previously [2,32].

2.4 Metabolic assessments. Some mice were used to investigate the effect of ghrelin on food intake, locomotor activity (beam breaks), whole $\mathrm{EE}(\mathrm{Kcal} / \mathrm{h})$, oxygen consumption and carbon dioxide production $\left(\mathrm{VO}_{2}, \mathrm{VCO}_{2}\right.$ where $\mathrm{V}$ is volume) and RER using calorimetric cages (Labmaster, TSE Systems $\mathrm{GmbH}$, Bad Homburg, Germany). Each cage combined a set of sensitive feeding and drinking sensors for automated online measurement and was embedded in a frame with an infrared light beams-based activity monitoring system, which allowed measurement of total locomotion. Ratio of gases was determined through an indirect open circuit calorimeter [33], which monitors $\mathrm{O}_{2}$ and $\mathrm{CO}_{2}$ concentration at the inlet ports of a tide cage through which a flow of air $(0.4 \mathrm{~L} / \mathrm{min})$ is ventilated and compared regularly to a reference empty cage. Whole EE was calculated according to the Weir equation [34]. The flow was calibrated with $\mathrm{O}_{2}$ and $\mathrm{CO}_{2}$ mixture of known concentration (Air Liquide, S.A. France). Mice were 
individually housed in metabolic cages 2 days before experimental measurements, at $22 \pm 1^{\circ} \mathrm{C}$ room temperature with food and water available ad libitum. Mice were daily IP injected with saline to minimize handling stress. On the experimental day, mice were IP injected with saline or ghrelin and monitored for 4 h. Data collection was recorded every $15 \mathrm{~min}$ during the whole experiments and data extracted was raw value of $\mathrm{VO}_{2}$ consumed, $\mathrm{VCO}_{2}$ produced $(\mathrm{mL} / \mathrm{h})$ and energy expended $(\mathrm{kcal} / \mathrm{h})$. This procedure was used on:

1. WT mice that were treated with either saline alone $(n=$ or containing $15(n=$ or $150(n=p m o l / g$ BW of ghrelin and remained with access to food.

2. WT mice that were treated with either saline alone $(n=$ or containing $15(n=$ or $150(n=p m o l / g$ BW of ghrelin and left with no access to food during the measurements.

3. $A R H^{A g R P} / \mathrm{NPY}$ neurons-ablated $(n=12)$ and control $(n=14)$ mice that were treated with $150 \mathrm{pmol} / \mathrm{g}$ BW of ghrelin and remained with access to food.

2.5 Food intake assessment. Food intake was manually assessed in ad libitum fed mice that were individually housed with limited amount of bedding in order to easily visualize chunks of pellets. Mice were individually housed 3 days before the experiments, with food and water available ad libitum, and daily IP injected with saline to minimize handling stress. On the experimental day, all food pellets were removed from the home cage hoppers and the bedding was confirmed to be free of chow remains. Then, mice were subjected to the different procedures/treatments and exposed to a single pre-weighed chow pellet $(\sim 1500 \mathrm{mg})$ in the floor of the home cages. Mice were injected with $60 \mathrm{pmol} / \mathrm{g}$ BW of ghrelin in all these experiments. Chow pellets together to any additional chow spillage were collected and weighed at $0.5,1,2,3,4$ and $5 \mathrm{~h}$ after food exposure using a calibrated scale that had a precision of $1 \mathrm{mg}$. Food intake was calculated subtracting the remaining weight of the pellet to the weight of the pellets at the previous time point, and expressed in $\mathrm{mg}$. This procedure was used on:

1. WT mice that had a delayed access to chow after In particular, mice were injected with saline or ghrelin and exposed to a food pellet immediately (saline $n=10$; ghrelin $n=$ or 1 (saline $n=16$; ghrelin $n=19), 2$ (saline $n=9$; ghrelin $n=9), 3$ (saline $n=19$; ghrelin $n=22), 4$ (saline $n=8$; ghrelin $n=$ or 5 (saline $n=9$; ghrelin $n=h$ after treatment.

2. ARH-intact $(n=$ and $A R H$-ablated $(n=$ mice that were injected with ghrelin and immediately exposed to a food pellet.

3. WT mice in which melanocortin receptor 4 (MC4was pharmacologically blocked after the first event of ghrelin-induced food Here, WT mice were first implanted with an ICV guide cannula, as we described in the past [35]. Then, ICV-cannulated mice were IP injected with ghrelin and immediately exposed to a food pellet. After $1 \mathrm{~h}$, mice were ICV injected with either artificial cerebrospinal fluid alone $(a C S F, n=7)$ or containing MT-II $(0.5 \mu \mathrm{g} /$ mouse, $n=6)$. The correct placement of the cannula was confirmed by histological observation at the end of the experiment.

4. WT mice in which the availability of plasma glucose was manipulated after the first event of ghrelininduced food Here, WT mice were initially injected with ghrelin and immediately exposed to a food 
Then, a set of mice was injected with vehicle alone ( $\mathrm{n}=$ or containing 2-deoxy-D-glucose $(250 \mathrm{mg} / \mathrm{Kg}$ $\mathrm{BW}, \mathrm{n}=$ at $0.5 \mathrm{~h}$ after ghrelin injection, whereas another set of mice was injected with vehicle alone ( $\mathrm{n}$ $=$ or containing glucose $(2.25 \mathrm{mg} / \mathrm{Kg} \mathrm{BW}, \mathrm{n}=$ at $1.5 \mathrm{~h}$ after ghrelin $\mathrm{In}$ this case, an independent set of WT mice was used to assess plasma glucose levels in mice that display ghrelin-induced food Briefly, ad libitum fed mice were IP injected with saline $(n=4)$ or ghrelin $(n=2)$ and returned to their home cages in the presence of food. Blood was sampled from the facial vein right at 0.5 and $1 \mathrm{~h}$ after treatment, and glycaemia was assessed using a glucometer (Accu-Chek ${ }^{\circledR}$ Performa). In addition, an independent set of ad libitum fed WT mice was used to assess plasma levels of glucose achieved at $0.5,1$ and $2 \mathrm{~h}$ after glucose treatment $(2.25 \mathrm{mg} / \mathrm{Kg} \mathrm{BW}, \mathrm{n}=4)$, as described above.

5. WT mice in which gastric emptying was blocked after the first event of ghrelin-induced food intake. Here, mice were IP injected with ghrelin and immediately exposed to a food pellet. After $1 \mathrm{~h}$, mice were IP injected with saline alone $(n=14)$ or containing hyoscine butyl-bromide $(6 \mathrm{mg} / \mathrm{Kg} \mathrm{BW}, \mathrm{n}=$ 13). In this case, an independent set of WT mice was first used to test the capability of such dose of hyoscine butyl-bromide to affect ghrelin-induced gastric emptying using the phenol red method [36, 37]. Briefly, ad libitum fed mice were administered by oral gavage with $0.1 \mathrm{~mL}$ of test solution $(0.5$ $\mathrm{mg} / \mathrm{mL}$ phenol red and $5 \%$ glucose in water). After $1 \mathrm{~min}$, mice were IP injected with ghrelin (60 $\mathrm{pmol} / \mathrm{g} \mathrm{BW})$ and immediately after with vehicle $(\mathrm{n}=8)$ or hyoscine butyl-bromide $(6 \mathrm{mg} / \mathrm{Kg} \mathrm{BW}, \mathrm{n}=$ 4). After $20 \mathrm{~min}$, mice were euthanized by decapitation and their stomachs were ligated at both ends and removed. Stomachs were homogenized in $0.1 \mathrm{~N} \mathrm{NaOH}$, proteins were precipitated using $20 \%$ trichloroacetic acid and further centrifugation. Finally, supernatants were mixed with $4 \mathrm{M} \mathrm{NaOH}$ and $540 \mathrm{~nm}$ absorbance was measured. Gastric emptying was expressed as a percentage and calculated according to the following equation: [1 - (absorbance in test stomach/average of initial absorbance)] $x 100$. The initial absorbance was obtained with an independent group of mice $(n=3)$, which was euthanized $1 \mathrm{~min}$ after the administration of the test solution and processed as described above.

6. WT mice that were treated with leptin after the first event of ghrelin-induced food In particular, WT mice were injected with ghrelin and immediately exposed to a food After $1 \mathrm{~h}$, mice were IP injected with vehicle alone $(n=$ or containing recombinant mouse leptin $(0.1 \mathrm{mg} / \mathrm{g} B W, n=15)$. Here, an independent set of WT mice was used to assess plasma leptin levels achieved under such experimental Briefly, ad libitum fed mice were treated with mouse leptin $(0.1 \mathrm{mg} / \mathrm{g} \mathrm{BW})$ and blood samples were obtained from the tail vein in heparin tubes right before treatment as well as at $0.5,1$ and $2 \mathrm{~h}$ after treatment. Plasma was separated by centrifugation and leptin levels were assessed using an enzymatic immunoassay from Linco Research (cat no. EZML-82K), as we have done in the past [29].

7. WT mice that were treated with CCK-8S after the first event of ghrelin-induced food WT mice were injected with ghrelin and immediately exposed to a food After $1 \mathrm{~h}$, mice were IP injected with vehicle alone $(n=$ or containing CCK-8S $(5 \mathrm{mg} / \mathrm{Kg} \mathrm{BW}, \mathrm{n}=10)$. The tested dose of CCK-8S was previously shown to be in the range that decreases food intake after a fasting period [30].

2.6 Immunohistochemistry. Individually housed WT mice were acclimated to handling 3 days before the experiment. On the experimental day, food was removed from the hoppers and mice were IP-injected with 
saline alone or containing ghrelin $(60 \mathrm{pmol} / \mathrm{g} \mathrm{BW})$. Mice remained without access to food and were anesthetized and transcardially perfused at 1 (saline $n=2$; ghrelin $n=4), 2$ (saline $n=7$; ghrelin $n=7$ ), 3 (saline $n=1$; ghrelin $n=4$ ), 4 (saline $n=2$; ghrelin $n=5$ ) or 5 (saline $n=1$; ghrelin $n=4$ ) h after treatment. Brains were removed, frozen and coronally cut at $45 \mu \mathrm{m}$. A series of brain sections was immuno-stained using an anti-c-Fos antibody (Santa Cruz, cat no. SC-7202). Briefly, sections were first incubated with $\mathrm{H}_{2} \mathrm{O}_{2} 0.5 \%$ and then blocked with normal donkey serum ( $\left.0.3 \%\right)$ diluted in PBS with Triton-X $(0.25 \%)$. Then, sections were sequentially incubated with the anti-c-Fos antibody $(1: 2000)$ for $48 \mathrm{~h}$ at $4^{\circ} \mathrm{C}$, a biotinylated anti-rabbit antibody (Jackson Immunoresearch, cat no. 111-065-003, 1:3000) for $1 \mathrm{~h}$ at $24^{\circ} \mathrm{C}$ and avidin-peroxidase complex (Vectastain Elite $A B C$ kit) following manufacture's protocol. Finally, immunoreactive signal was revealed with a $D A B /$ nickel solution that generates a black nuclear precipitate in c-Fos positive (c-Fos+) cells. Sections were mounted on glass slides and coverslipped with mounting media. The number of c-Fos + cells in the ARH was bilaterally estimated in coronal sections between bregma -1.58 and $-2.06 \mathrm{~mm}$, using the anatomical limits described in the mouse brain atlas [38]. Lowmagnification bright-field representative images were acquired with a Nikon Eclipse 50i and a DS-Ri1 Nikon digital camera.

A similar study was performed using NPY-GFP mice. Briefly, individually housed NPY-GFP mice were IP injected with saline alone $(n=3)$ or containing ghrelin ( $60 \mathrm{pmol} / \mathrm{g} \mathrm{BW})$. One group of ghrelin-injected NPYGFP mice remained with access to food $(n=3)$, while a second group $(n=5)$ were kept in their home cages in the absence of food for $3 \mathrm{~h}$. Then, mice were perfused and their brains were obtained and coronally cut. A series of sections was processed as described above and incubated with the anti-c-Fos antibody $(1: 1000)$ for $48 \mathrm{~h}$ at $4^{\circ} \mathrm{C}$. Finally, the immuno-reactivity was visualized using a red Alexa594conjugated anti-rabbit antibody (Invitrogen, cat no. A11008, 1:1000) for $2 \mathrm{~h}$ at $24^{\circ} \mathrm{C}$. Sections were mounted on glass slides and coverslipped with mounting media. Fluorescent images were acquired with a Zeiss AxioObserver D1 equipped with an Apotome.2 structured illumination module and an AxioCam 506 monochrome camera. The number of GFP-expressing, c-Fos + and double c-Fos+/GFP-expressing cells were estimated in the $\mathrm{ARH}$, as described above. The relationship was expressed as a percentage, which represents c-Fos+/GFP-expressing cells compared with the total number of GFP-expressing cells, or c-Fos+/GFP-expressing cells compared with the total number of c-Fos + cells.

2.7 Quantification of mRNA levels in the hypothalamus. Individually housed WT mice were IP injected with vehicle alone or containing ghrelin (150 pmol/g BW). Mice remained without access to food and were euthanized by decapitation at 1 (vehicle $n=4$, ghrelin $n=6), 3($ vehicle $n=4$, ghrelin $n=6$ ) or 5 (vehicle $n=4$, ghrelin $n=5$ ) $h$ after treatment. Brains were extracted and placed in a mouse brain matrix with the ventral surface on top and cut using the optic chiasm and rostral edge of mamillary bodies as rostral and caudal limits, respectively. Hypothalamic sulci were used as lateral limits and a $1.5 \mathrm{~mm}$-thick slice was taken parallel to the base of the hypothalamus. Hypothalamus were collected in TRIzol Reagent (Invitrogen Inc), and total RNA was isolated according to the manufacturer's protocol. To remove residual DNA contamination, the RNA samples were treated with RNAse-free DNAse (Qiagen). The concentration of RNA samples was ascertained by measuring optical density at $260 \mathrm{~nm}$. The RNA integrity was 
confirmed by the detection of $18 \mathrm{~S}$ and $28 \mathrm{~S}$ bands after agarose-formaldehyde gel electrophoresis, and RNA quality was verified by optical density absorption ratio $260 \mathrm{~nm} / 280 \mathrm{~nm}$. Total RNA from each sample was reverse-transcribed into cDNA using random hexamer primers and M-MLV reverse transcriptase (Invitrogen, Life Technologies). Real time quantitative PCR for NPY, AgRP and POMC was carried out using SsoAdvanced Universal SYBR Green Supermix (Bio-Rad, cat no. 172-5271). All reactions were carried out in duplicate with no template control. Product purity was confirmed by dissociation curves, and random samples were subjected to agarose gel electrophoresis. Fold change from vehicle-treated mice values was determined using the relative standard curve method, normalizing the expression to the ribosomal protein L19 (reference gene). Primers sequences for NPY were sense: $5^{\prime}-$

GCCAGATACTACTCCGCTCTG-3', antisense: 5'-GATCTCTTGCCATATCTCTGTCTG-3' [GenBank Accession No. NM_023456.3], product size 68 bp. Primers sequences for AgRP were sense: 5'-

TTGGCAGAGGTGCTAGATCCA-3', antisense: 5'-AGGACTCGTGCAGCCTTACAC-3' [GenBank Accession No. NM_033650.1], product size 108 bp. Primers sequences for L19 were sense: 5'AGCCTGTGACTGTCCATTCC-3', antisense: 5'-TGGCAGTACCCTTCCTCTTC-3' [GenBank Accession No. NM_009078.2], product size 99 bp.

2.8 Statistical analyses. All statistical analyses were performed using GraphPad Prism 6.0 and differences were considered significant when $\mathrm{P}<0.05$. The rapid and delayed time periods in each experiment were determined as the timepoints in which a significant difference was obtained from control groups plus the timepoints immediately before and after. No significant differences $(P>0.09)$ were observed between the number of c-Fos + cells in the ARH of vehicle-treated mice that were perfused $1(n=2), 2(n=7), 3(n=1), 4(n=2)$ or $5(n=1)$ h after treatment and thus their data were pooled and termed vehicle-treated group. All statistical tests performed are indicated in the figure captions.

\section{Results}

3.1 Ghrelin treatment induces rapid and delayed effects on food intake, EE and the RER in ad libitum fed mice. We tested three doses of ghrelin: 15,60 and $150 \mathrm{pmol} / \mathrm{g} \mathrm{BW}$, among which $15 \mathrm{pmol} / \mathrm{g} \mathrm{BW}$ was the minimum dose of ghrelin that significantly increased food intake, and $150 \mathrm{pmol} / \mathrm{g}$ BW was the minimum dose of ghrelin that induced maximal food intake response under our experimental conditions. The 15 $\mathrm{pmol} / \mathrm{g} \mathrm{BW}$ dose induced a 50-fold increase of plasma ghrelin levels at $0.25 \mathrm{~h}$ post-treatment that returned to basal levels at $0.75 \mathrm{~h}$ post-treatment whereas the $150 \mathrm{pmol} / \mathrm{g} \mathrm{BW}$ dose induced a $\sim 250$-fold increase of plasma ghrelin levels at $0.25 \mathrm{~h}$ post-treatment that returned to basal levels at $1 \mathrm{~h}$ posttreatment (Fig. 1). We first investigated the effects of the lower and the higher dose of ghrelin on food intake, locomotor activity, EE and the RER using automated measure of $\mathrm{O}_{2}, \mathrm{CO}_{2}$, feeding and activity. Both doses of ghrelin rapidly increased food intake. The low dose of ghrelin increased food intake at $0.5 \mathrm{~h}$ post-treatment, while the high dose of ghrelin increased food intake at 0.5 and $0.75 \mathrm{~h}$ post-treatment. Interestingly, both doses of ghrelin induced a delayed increase of food intake at $2.5 \mathrm{~h}$ post-treatment (Fig. 2a). Analysis of cumulative food intake indicated that both doses of ghrelin significantly increased 
food intake in the 0.25 -to-1.0 $\mathrm{h}$ and the 2.25 -to-2.75 $\mathrm{h}$ post-treatment periods (hereafter named rapid and delayed effects, Fig. 2b).

Both doses of ghrelin induced a 1.4-fold increase of locomotor activity at $0.5 \mathrm{~h}$ post-treatment, while only the low dose of ghrelin induced a significant increase in locomotor activity at $2.5 \mathrm{~h}$ post-treatment (Fig. 2c). In terms of cumulative locomotor activity, only the low dose of ghrelin induced a significant rapid effect (Fig. 2d). Regarding EE, the low dose of ghrelin induced a transient stimulatory effect at $2.5 \mathrm{~h}$ post-treatment while the high dose of ghrelin affected EE at 0.5, 1.25 and $1.5 \mathrm{~h}$ after treatment (Fig. 2e). In terms of cumulative $\mathrm{EE}$, both doses of ghrelin induced a delayed decrease in $\mathrm{EE}$ that only reached statistical significance for the low dose of ghrelin (Fig. 2f). The low dose of ghrelin significantly increased the RER at $0.75,1.0$ and 1.25 h post-treatment, while the high dose of ghrelin significantly increased the RER from $0.75 \mathrm{~h}$ post-treatment until $4 \mathrm{~h}$ post-treatment, when the measurements were stopped (Fig. $2 \mathrm{~g}$ ). Since the effect of ghrelin on the RER seemed to occur right after the rapid ghrelin-induced increase of food intake, we calculated the rapid and delayed effects of ghrelin on the RER in the 1.0-to-1.75 $\mathrm{h}$ and in the 3.0-to-3.5 $\mathrm{h}$ periods of time, respectively, after the rapid and delayed effects of ghrelin on food intake. Ghrelin treatment induced a significant dose-response effect on the rapid changes in the RER, while only the high dose of ghrelin displayed a positive effect on the delayed changes in the RER (Fig. 2h).

3.2 Ghrelin treatment does not affect EE and the RER in mice that are not allowed to eat. In order to test if the effects of ghrelin on EE and the RER were secondary to ghrelin-induced food intake, we investigated the effects of ghrelin on locomotor activity, EE and the RER in mice that were housed in calorimetric cages but were not allowed to eat after ghrelin treatment. In this case, the high dose of ghrelin transiently increased locomotor activity at $1.0 \mathrm{~h}$ post-treatment (Fig. 3a), while none of ghrelin doses significantly affected cumulative locomotor activity (Fig. 3b). The high dose of ghrelin also transiently increased EE at $0.5 \mathrm{~h}$ post-treatment (Fig. 3c), but none of ghrelin doses significantly affect cumulative EE (Fig. 3d). The high dose of ghrelin transiently decreased the RER at $0.5 \mathrm{~h}$ post-treatment (Fig. 3e), but both ghrelin doses failed to significantly change the RER (Fig. 3f).

3.3 Ghrelin treatment involves long-term orexigenic effects that involve the ARH. First, we estimated how long the orexigenic effect of ghrelin lasts after treatment. For this purpose, a set of mice was injected with ghrelin and exposed to food at $0,1,2,3,4$ or $5 \mathrm{~h}$ after injection. Here, mice were injected with $60 \mathrm{pmol} / \mathrm{g}$ BW of ghrelin, a dose that consistently increased food intake in our experimental conditions and induced a rapid increase of plasma ghrelin levels that returned to basal levels at $0.75 \mathrm{~h}$ after treatment, similar as seen for the low dose of ghrelin, as described above (Fig. 1). Ghrelin treatment rapidly increased food intake in mice that had immediate access to food as well as in mice that were exposed to food at 1, 2, 3 and $4 \mathrm{~h}$ after injection (Fig. 4a). Thus, ghrelin seemed to induce a persistent orexigenic effect that lasted for $\sim 4 \mathrm{~h}$. In order to test if a single injection of ghrelin induces a long-lasting activation of ARH neurons, we estimated the number of c-Fos + cells in the ARH of mice that were perfused 1, 2, 3, 4 or $5 \mathrm{~h}$ after ghrelin treatment and had no access to food (Fig. 4b-C). Interestingly, ghrelin increased the number of cFos + cells in the ARH at 1, 2 and $3 \mathrm{~h}$ after treatment (Fig. $4 \mathrm{~b}$ ). Then, we tested if the ARH is required for the rapid and delayed effects of ghrelin on food intake, and for this purpose we tested the effect of 
systemically injected ghrelin in $\mathrm{ARH}$-ablated mice, which show a selective ablation of this hypothalamic region (Fig. 4d) but conserved the morphology of other brain regions [4]. Manual assessment of food intake indicated that ghrelin treatment induced rapid and delayed increments of food intake in ARH-intact mice, similar as revealed by the automatized method in WT mice. In contrast, ghrelin treatment did not induce rapid nor delayed increments of food intake in ARH-ablated mice (Fig. 4e) suggesting that the orexigenic effects of ghrelin at both periods require the presence of the ARH.

3.4 The rapid and delayed orexigenic effects of ghrelin treatment involve ARH AgRP/NPY neurons. In order to investigate the role of $A R H^{A g R P / N P Y}$ neurons on the rapid and delayed orexigenic effects of ghrelin, we tested the orexigenic effect of systemically injected ghrelin in mice with selective ablation of $A R H^{A g R P / N P Y}$ neurons. Ghrelin treatment did not induce rapid nor delayed increments of food intake in ARHAgRP/NPY neurons-ablated mice (Fig. 5a), suggesting that both orexigenic effects of ghrelin require the presence of the $A R H^{A g R P / N P Y}$ neurons. In order to test if the long-term effect of ghrelin on c-Fos in the ARH involves $A R H^{A g R P / N P Y}$ neurons, we injected ghrelin to NPY-GFP mice that had no access to food after treatment and perfused them at $3 \mathrm{~h}$ after treatment. We found that ghrelin increased the fraction of GFP-expressing cells positive for c-Fos, which represent $9.2 \pm 2.2$ and $0.0 \pm 0.0 \%$ of all GFP-expressing cells in ghrelin- and vehicle-treated mice, respectively (Fig. 5b). To test if ghrelin induced c-Fos in ARH AgRP/NPY neurons is affected by food intake, we assessed the fraction of GFP-expressing cells positive for c-Fos in the ARH of NPY-GFP mice that were allowed to eat after ghrelin treatment and found that $9.1 \pm 0.2$ and $0.0 \pm 0.0 \%$ of all GFP-expressing cells were positive for c-Fos in ghrelin- and vehicle-treated mice, respectively. Thus, $\mathrm{ARH}^{\mathrm{AgRP} / \mathrm{NPY}}$ neurons remained active $3 \mathrm{~h}$ after ghrelin treatment independently of food intake. In order to test if ghrelin increases the expression of the orexigenic peptides NPY and AgRP, we assessed hypothalamic mRNA levels of NPY and AgRP in WT mice that were sacrificed 1, 3 and $5 \mathrm{~h}$ after ghrelin treatment. We found that ghrelin increased NPY mRNA levels at $1 \mathrm{~h}$ after treatment (Fig. 5c) and AgRP mRNA levels at 1 and $3 \mathrm{~h}$ after treatment, as compared to vehicle treatment (Fig. $5 \mathrm{~d}$ ). Since the delayed increase of food intake in response to ghrelin correlated with an increase of AgRP mRNA levels, we assessed delayed ghrelin-induced food intake in WT mice in which AgRP action was pharmacologically blocked using ICV administration of the melanocortin 3/4 receptor ligand MT-II, which compete with AgRP action. We found that mice ICV injected with MT-II showed a decreased delayed ghrelin-induced food intake, as compared to mice ICV injected with vehicle (Fig. 5e).

3.5 The orexigenic effect of ghrelin is transiently counteracted by satiation signals. Our results indicate that ghrelin treatment induces a long-lasting activation of ARH neurons that correlates with a long-term orexigenic effect, which can be unmasked even $4 \mathrm{~h}$ after treatment in mice that were not allowed to eat. Since ghrelin-induced food intake involves a rapid and a delayed intake event in mice that are allowed to eat, we hypothesized that the orexigenic effect of ghrelin is transiently neutralized by the activation of post-prandial pathways that take place after the rapid event of food intake. Food intake increases plasma glucose levels [39, 40], and hyperglycemia has been shown to reduce ghrelin-induced food intake [41]. Under our experimental conditions, plasma glucose levels transiently increased at $0.5 \mathrm{~h}$ after ghrelin treatment in mice allowed to eat ( $247 \pm 22 \mathrm{vs.} 163 \pm 1 \mathrm{mg} / \mathrm{dL}$ in vehicle-treated mice), and then return to 
basal levels at $1 \mathrm{~h}$ post-treatment ( $166 \pm 2 \mathrm{vs.} 172 \pm 10 \mathrm{mg} / \mathrm{dL}$ in vehicle-treated mice). Thus, we theorized that the post-prandial increment of glycaemia could transiently counteract the orexigenic effects of ghrelin treatment, and hypothesized that blocking or increasing glucose availability after the first event of food intake could affect the delayed event of ghrelin-induced food intake. In order to increase or decrease the availability of glucose after the rapid increase of food intake, mice were injected with glucose or the non-metabolizable glucose analogue 2-deoxy-glucose (2-DG), respectively. Glucose treatment transiently increased plasma glucose levels, which were $242 \pm 29,180 \pm 12$ and $171 \pm 30 \mathrm{mg} / \mathrm{dL}$ at $0.5,1$ and $2 \mathrm{~h}$ after treatment, and did not affect food intake in mice that were not treated with ghrelin (not shown). In ghrelin-treated mice, however, glucose treatment abrogated the delayed effect of ghrelin on food intake (Fig. 6a). In mice that were not treated with ghrelin, 2-DG treatment rapidly and transiently increased food intake exclusively in the 0.5 -to- $1.0 \mathrm{~h}$ post-treatment period $(92.3 \pm 37.0$ vs. $27.3 \pm 10.2 \mathrm{mg}, P=0.03)$. In ghrelin-treated mice, 2-DG treatment also increased food intake in the 0.5-to-1.0 h post-treatment period, which occurred after the rapid event of ghrelin-induced food intake, and then increased the magnitude of the delayed effect of ghrelin on food intake (Fig. 6b).

After meals, plasma CCK levels also increase [42], and the simultaneous administration of ghrelin and CCK was shown to abrogate ghrelin-induced food intake in rats [43]. Food intake causes gastric filling, and the post-prandial increase of gastric size is a well-established factor that reduces eating $[44,45]$. Thus, we theorized that manipulating gastric filling or the post-prandial elevation of plasma CCK levels could affect the delayed event of ghrelin-induced food intake. In order to test our hypothesis, mice were first treated with ghrelin and then injected with CCK-8S or the anticholinergic agent hyoscine butylbromide [46, 47], in a dose that was confirmed to reduce ghrelin-stimulated gastric emptying as compared to vehicle-treated mice ( $7.0 \pm 3.7$ vs. $46.3 \pm 4.1 \%$ of gastric emptying, respectively). We found that both CCK-8S and hyoscine butyl-bromide impaired the capability of ghrelin to induce a delayed increment of food intake (Fig. $6 \mathrm{c}-\mathrm{d}$ ). Since leptin pre-treatment also impairs the rapid orexigenic effect of ghrelin in rats [48], we tested if leptin treatment after the rapid event of ghrelin-induced food intake could modulate the delayed orexigenic effects of ghrelin. In leptin-treated mice, plasma leptin levels were $3.1 \pm 0.6,62.3 \pm 8.5$, $34.5 \pm 5.6$ and $25.1 \pm 2.7 \mathrm{ng} / \mathrm{mL}$ at $0,0.5,1$ and $2 \mathrm{~h}$ after treatment. Leptin treatment after the rapid event of ghrelin-induced food intake abrogated the capability of ghrelin to induce a delayed increment of food intake (Fig. 6e).

\section{Discussion}

Here, we provide a compelling characterization of food intake, locomotor activity, EE and RER in mice systemically treated with ghrelin. We found that ghrelin treatment induces a rapid and a delayed increment of food intake as well as a biphasic, although less robust, effect on locomotor activity. Ghrelin treatment also induced slower inhibitory and stimulatory effects on EE and RER, respectively. The main effects of ghrelin on locomotor activity, EE and RER seemed to depend on food intake, as ghrelin-treated mice that were food deprived during the measurements showed marginal changes in these parameters. Furthermore, we found that a bolus of ghrelin resulted in both a long-lasting activation of the ARH, and a long-lasting orexigenic effect. The rapid and delayed effects of ghrelin on food intake seem to involve a 
sustained activation of the ARH ${ }^{A g R P / N P Y}$ neurons. Finally, we provided evidence that some post-prandial satiation signals transiently counteract the stimulatory effect of ghrelin on food intake.

Some technical aspects of our experiments should be considered for a more accurate interpretation of the results. We choose to assess mice behavior in the morning in order to increase our capability to detect the effects of ghrelin, as food intake, locomotor activity, EE and RER are low in the morning [49]. All tested doses of ghrelin induced transient supraphysiological increments of ghrelin levels, which are known to be required to consistently detect food intake responses to ghrelin [6]. Thus, current findings address the effects of ghrelin treatment, but their physiological implications are uncertain. The lowest dose of ghrelin tested transiently mimicked the hormone levels detected in severely calorie restricted mice, in which a 12-18-fold increase of ghrelin levels is detected, as compared to ad libitum fed mice [3]. However, plasma ghrelin levels remain elevated during long periods of time (e.g. days) under energy deficit states [3]. In addition, such sustained elevations of ghrelin levels are concomitant to a countless number of neuroendocrine adaptions, including an increment of GHSR gene expression in the ARH and a GHSRdependent remodeling of hypothalamic neuronal circuits, which may affect the sensitivity to ghrelin $[2,50]$. Thus, our experimental conditions may mimic the impact of lower increments of plasma ghrelin levels in some specific metabolic conditions. Finally, it is important to stress that food intake and locomotor activity were assessed as accumulated values every $0.25 \mathrm{~h}$; in contrast, RER and EE were assessed every $0.25 \mathrm{~h}$ and reported as the average values at each time point. Such different sampling rate, which was inherent to the metabolic chambers design, have limited our capability to perform some correlation analysis.

Both the lower and the higher doses of ghrelin induced a similar $\sim 4$-fold increase of food intake at $0.5 \mathrm{~h}$ post-treatment, but the highest dose of ghrelin induced a longer orexigenic effect, which remained significant at $0.75 \mathrm{~h}$ post-treatment. Despite the 10 times difference in the dose of ghrelin, the rapid ghrelin-induced food intake event showed a poor dose-response profile, as it has been previously reported by us and by others $[4,6,7,51]$ and may be attributed to a ceiling effect. The ghrelin-induced delayed event of food intake involved an $~ 50 \%$ less food eaten, as compared to the rapid event, usually took place at $\sim 2.5 \mathrm{~h}$ post-treatment (although sometimes was detected $\sim 3.0 \mathrm{~h}$ post-treatment), and also lacked a doseresponse profile. Such biphasic pattern of ghrelin-induced food intake was observed using either automated or manual strategies to measure food intake and, to our knowledge, has not been reported before.

Ghrelin treatment induced slights increments of locomotor activity at 0.5 and $2.5 \mathrm{~h}$ post-treatment. The capability to detect significant effects of ghrelin on locomotor activity depended on the way data was processed (compare 2c vs $2 d$ ) suggesting that this effect of ghrelin is less robust than ghrelin-induced food intake. Such mild effect of ghrelin on locomotor activity detected at specific time points posttreatment together to the fact that locomotor activity can be assessed using different experimental strategies (e.g. beam breaks, video tracking, etc.) may explain previous inconsistencies in terms of the reported ghrelin's effects on locomotor activity [17-21]. Due to the sampling rate of food intake and locomotor activity, we could not determine if locomotor activity occurred in anticipation to food intake. 
However, the fact that ghrelin treatment did not induce locomotor activity in mice that were not allowed to eat suggests that ghrelin did not promote ambulatory activity. Rather, the locomotor behaviors detected in ghrelin-treated mice exposed to food may be related to behavioral rituals associated to food consumption.

Total EE includes resting EE, activity-induced EE and diet-induced EE, which refers to the post-prandial increase of thermogenesis due to the stimulation of energy-requiring processes [52]. Since ghrelin increased food intake and locomotor activity, we expected to detect a ghrelin-induced increase of EE in mice with access to food. This prediction was correct at $2.5 \mathrm{~h}$ post-treatment, when ghrelin increased $\mathrm{EE}$ in parallel to the delayed ghrelin-induced food intake and locomotor activity. Such delayed stimulatory effect of ghrelin on EE appears to depend on food intake and locomotor activity since it was not observed in ghrelin-treated mice that were not allowed to eat. The effect of ghrelin on EE at the beginning of the experiment was less evident. The higher dose of ghrelin decreased EE at $0.5,1.25$ and $1.5 \mathrm{~h}$ posttreatment, in mice that were allowed to eat, but ghrelin did not induce a net effect in the cumulative EE in this time period (Panel 2f), when ghrelin-induced food intake and locomotor activity were highest. Thus, it could be interpreted that ghrelin initially decreases $E E$, until $1.5 \mathrm{~h}$ post-treatment, in a magnitude that transiently neutralizes the food intake- and locomotor activity-induced increase of EE. In line with this possibility, it was shown that systemically-injected ghrelin decreases EE, in the 0.5-1.0 h post-treatment period, in mice without access to food [22]. However, we could not confirm these observations (Panel 2cd). Of note, some studies have inferred that ghrelin decreases EE based on the observations that ghrelin decreased UCP1 gene expression in BAT [53] or that ghrelin suppressed BAT sympathetic nerve activity and BAT temperature [54]; however, these studies did not directly assess the effect of ghrelin on EE. Overall, the current study indicates that ghrelin treatment does not affect total EE in a physiologically relevant manner. It remains to be determined if ghrelin differentially affects resting $E E$, diet-induced $E E$ or activity-induced EE.

Ghrelin treatment induced a robust and dose-response stimulatory effect on the RER, which was absent in ghrelin-treated mice without access to food, suggesting that this effect of ghrelin fully depends on the post-prandial metabolism. At the beginning of the experiment, mice showed a RER of $\sim 0.8$, which is a typical value for metabolism depending on lipid oxidation [33]. Then, ghrelin-treated mice show a $\sim 0.15$ increase of the RER starting at $0.75 \mathrm{~h}$ post-treatment, right after the rapid event of ghrelin-induced food intake, indicating that the mouse metabolism moved towards a higher oxidation of carbohydrates, the main component of the standard chow [33]. Then, another delayed ghrelin-induced increment of the RER is detected after $2.5 \mathrm{~h}$ post-treatment, right after the delayed effect of ghrelin on food intake. Our observations are in accordance to previous reports showing that ghrelin increases the RER of rats in a food intake-dependent manner $[23,55]$.

We show here that a single injection of ghrelin, which transiently increased plasma ghrelin levels for less than $1 \mathrm{~h}$, increased food intake and c-Fos levels in the ARH for $\sim 4 \mathrm{~h}$ after treatment in mice that were maintained without access to food. As described in the introduction section, ARHAgRP/NPY neurons are a well-established direct and indirect target of ghrelin [56,57]. Ghrelin does not increase food intake in 
double NPY and AgRP knock-out mice [58]. Furthermore, GHSR expression exclusively in ARHAgRP/NPY neurons is required and sufficient for the rapid stimulatory effects of ghrelin on food intake [14,15]. Here, we extent previous findings by showing that ghrelin failed to induce not only rapid but also delayed effects on food intake in ARH-ablated mice and in ARH ${ }^{A g R P / N P Y}$ neurons-ablated mice. Moreover, we found that: 1) a subset of $A R H^{A g R P / N P Y}$ neurons remain active $3 \mathrm{~h}$ after ghrelin treatment, even in mice that eat after treatment, 2) AgRP gene expression remains elevated at $3 \mathrm{~h}$ after ghrelin treatment, and 3) the pharmacological blockage of AgRP signaling, after the rapid event of ghrelin-induced food intake, abrogates the delayed effect of ghrelin on food intake. Altogether, these observations indicate that the long-term orexigenic effect of ghrelin involves a sustained activation of AgRP signaling. In line with these observations, it was reported that 5 min incubation of hypothalamic slices from fed mice with ghrelin increased the stimulatory inputs on $A R H^{A g R P / N P Y}$ neurons for even $5 \mathrm{~h}$ after exposure [57], suggesting that ghrelin can induce long-term effects on $A R H^{A g R P / N P Y}$ neurons. Notably, in vivo studies have shown that a brief stimulation of $A R H^{A g R P / N P Y}$ neurons induces long-term feeding effects. For instance, 1 min optogenetic stimulation of $\mathrm{ARH}^{\mathrm{AgRP} / \mathrm{NPY}}$ neurons induced voracious feeding in mice that had access to food $0.5 \mathrm{~h}$ later [59]. Also, acute pharmacogenetic activation of $A R H^{A g R P / N P Y}$ neurons, using a drug that has a half-life $<1 \mathrm{~h}$, induced a sustained increase of food intake that is observed several days after treatment [60]. Thus, optogenetic and pharmacogenetic studies support the notion that a transient elevation of plasma ghrelin could induce a long-term activation of $A R H^{A g R P / N P Y}$ neurons and promote food intake several hours later. Worth of note, the orexigenic effects of centrally administered NPY and AgRP show different dynamics: NPY immediately induces feeding, whereas AgRP displays a delayed effect on food intake that lasts over $24 \mathrm{~h}$ [61]. Seminal optogenetic studies showed that activation of the $\mathrm{ARH}^{\mathrm{AgRP} / \mathrm{NPY}}$ neurons rapidly -at $\sim 6$ min after stimulation- induces a feeding event that involves GABA release in the hypothalamic paraventricular nucleus, and does not depend on the melanocortin system $[9,62]$. Similarly, pharmacogenetic studies in genetically-modified mice lacking GABA, NPY, AgRP and/or MC4R showed that NPY and GABA mainly mediate the rapid orexigenic effects of $A R H^{A g R P / N P Y}$ neurons stimulation, whereas AgRP requires at least $2 \mathrm{~h}$ to increase food intake [63]. Further studies performing optogenetic activation of the ARH ${ }^{A g R P / N P Y}$ neurons confirmed that NPY mediate the initial (tens of minutes) increase of food intake [64]. Thus, current and previous observations support the notion that the delayed orexigenic effects of ghrelin would mainly involve the AgRP signaling.

The orexigenic effect of ghrelin treatment persisted for $\sim 4 \mathrm{~h}$, but ghrelin induced a biphasic increase of food intake. Thus, we hypothesized that the orexigenic effect of ghrelin was transiently counteracted by post-prandial satiation mechanisms induced by the rapid event of ghrelin-induced food intake. Since food intake transiently elevates plasma levels of glucose, which is a potent satiation signal, we investigated the effect of manipulating post-prandial glucose availability and found that the delayed event of ghrelininduced food intake was abrogated or enhanced in mice treated with either glucose or 2-DG, respectively. The mechanisms by which glucose availability affects the delayed event of ghrelin-induced food intake remain uncertain. A previous study showed that glucose pre-treatment impairs the effects of ghrelin on both food intake and NPY/AgRP gene expression via a mechanism that involves the energy sensing 
enzyme AMP-activated protein kinase in $A R H^{A g R P / N P Y}$ neurons [28]. Here, glucose was administered after the rapid effect of ghrelin on food intake and may have also reduced the delayed event of ghrelin-induced food intake by recruiting other satiation signals (e.g., insulin or CCK). Conversely, ghrelin and 2-DG were shown to display an additive effect on food intake that does not require AMP-activated protein kinase in $A R H^{A g R P / N P Y}$ neurons [28]. Here, we found that 2-DG treatment enhances the delayed event of ghrelininduced food intake, independently of its own orexigenic effect, suggesting that glucopenia also downregulate other satiation signals. Thus, the long-term orexigenic effect of ghrelin seems susceptible to be counteracted by different satiation signals. In line with this possibility, we found that the delayed effect of ghrelin on food intake was abrogated in mice treated, after the first event of ghrelin-induced food intake, with either hyoscine butyl-bromide, an anticholinergic drug [65] that slows gastric emptying, leptin or CCK. The molecular mechanisms by which the anorexigenic inputs sculpt the long-term orexigenic effect of ghrelin remains to be determined. Some anorexigenic inputs may directly act on the ARHAgRP/NPY neurons. For instance, the intestinal distention inhibits $A R H^{A g R P / N P Y}$ neurons via stimulation of intestinal mechanoreceptors [66], and leptin potently abrogates ghrelin-induced activation of $A R H^{A g R P / N P Y}$ neurons, which are among the few neuronal type expressing receptors for ghrelin and leptin $[67,68]$. CCK can also directly act at the $\mathrm{ARH}$, where it inhibits $\mathrm{ARH} \mathrm{AgRP}^{\mathrm{ANPY}}$ neurons and blocks ghrelin-induced expression of cFos $[43,69,70]$. However, CCK is thought to mainly inhibit food intake via vagal afferents pathways and also potently reduce gastric emptying that can, in turn, affect ghrelin-induced food intake [71]. Then, further studies are required to elucidate the intricacies of the mechanisms sculpting the long-term orexigenic effect of ghrelin.

Based on our observations, we propose a hypothetical model to describe ghrelin's effects on energy balance (Fig. 7). Basically, ghrelin primarily induces food intake that has indirect consequences on $E E$, the RER and satiation signals. The net ghrelin-induced food intake results from the integration of orexigenic mechanisms activated by ghrelin and anorexigenic mechanisms secondary to food intake. We hope this simple model represents a useful tool to facilitate the understanding of the complex mechanisms underlying ghrelin's actions on energy balance, and has applications for a better use of future pharmacological therapies aimed to manipulate the ghrelin system.

\section{Declarations}

Ethics approval and consent to participate: N/A

Consent for publication: N/A

Availability of data and material: All data generated or analysed during this study are included in this published article and are available from the corresponding author on reasonable request.

Conflicts of interest/Competing interests: The authors have nothing to disclose. 
Funding: This work was supported by grants from the Fondo para la Investigación Científica y Tecnológica (FONCyT, PICT2016-1084 and PICT2017-3196) and from CONICET (PUE-2017) to MP. MPC and GF were supported by CONICET.

Authors' contributions: MPC, RGPD, GGR, GF and MR performed the experiments. MPC, MP, RGPD and SL designed the experiments and wrote the manuscript.

Acknowledgments: We would like to thank to Dr. Marcelo Vatta from the University of Buenos Aires for providing CCK-8S.

Authors' information: María Paula Cornejo, Guadalupe García Romero, Gimena Fernández, Mirta Reynaldo and Mario Perello work at Laboratory of Neurophysiology of the Multidisciplinary Institute of Cell Biology [IMBICE, Argentine Research Council (CONICET) and Scientific Research Commission, Province of Buenos Aires (CIC-PBA), National University of La Plata], 1900 La Plata, Buenos Aires, Argentina. Raphaël G.P. Denis and Serge Luquet work at Université de Paris, Unité de Biologie Fonctionnelle et Adaptative (BFA), UMR 8251, CNRS, F-75013 Paris, France.

\section{References}

[1] Yanagi S, Sato T, Kangawa K, Nakazato M. The Homeostatic Force of Ghrelin. Cell Metabolism 2018;27:786-804. https://doi.org/10.1016/j.cmet.2018.02.008.

[2] Fernandez G, Cabral A, Andreoli MF, Labarthe A, M'Kadmi C, Ramos JG, et al. Evidence Supporting a Role for Constitutive Ghrelin Receptor Signaling in Fasting-Induced Hyperphagia in Male Mice. Endocrinology 2018;159:1021-34. https://doi.org/10.1210/en.2017-03101.

[3] Zhao T-J, Liang G, Li RL, Xie X, Sleeman MW, Murphy AJ, et al. Ghrelin O-acyltransferase (GOAT) is essential for growth hormone-mediated survival of calorie-restricted mice. Proceedings of the National Academy of Sciences 2010;107:7467-72. https://doi.org/10.1073/pnas.1002271107.

[4] Cabral A, Valdivia S, Fernandez G, Reynaldo M, Perello M. Divergent Neuronal Circuitries Underlying Acute Orexigenic Effects of Peripheral or Central Ghrelin: Critical Role of Brain Accessibility. J Neuroendocrinol 2014;26:542-54. https://doi.org/10.1111/jne.12168.

[5] Kuo Y-T, Parkinson JRC, Chaudhri OB, Herlihy AH, So P-W, Dhillo WS, et al. The Temporal Sequence of Gut Peptide-CNS Interactions Tracked In Vivo by Magnetic Resonance Imaging. J Neurosci 2007;27:12341-8. https://doi.org/10.1523/JNEUROSCI.2391-07.2007.

[6] McFarlane MR, Brown MS, Goldstein JL, Zhao T-J. Induced Ablation of Ghrelin Cells in Adult Mice Does Not Decrease Food Intake, Body Weight, or Response to High-Fat Diet. Cell Metabolism 2014;20:5460. https://doi.org/10.1016/j.cmet.2014.04.007. 
[7] Wren AM, Seal LJ, Cohen MA, Brynes AE, Frost GS, Murphy KG, et al. Ghrelin Enhances Appetite and Increases Food Intake in Humans. J Clin Endocrinol Metab 2001;86:5992-5992. https://doi.org/10.1210/jcem.86.12.8111.

[8] Andermann ML, Lowell BB. Toward a Wiring Diagram Understanding of Appetite Control. Neuron 2017;95:757-78. https://doi.org/10.1016/j.neuron.2017.06.014.

[9] Aponte Y, Atasoy D, Sternson SM. AGRP neurons are sufficient to orchestrate feeding behavior rapidly and without training. Nat Neurosci 2011;14:351-5. https://doi.org/10.1038/nn.2739.

[10] Krashes MJ, Koda S, Ye C, Rogan SC, Adams AC, Cusher DS, et al. Rapid, reversible activation of AgRP neurons drives feeding behavior in mice. J Clin Invest 2011;121:1424-8. https://doi.org/10.1172/JCl46229.

[11] Gropp E, Shanabrough M, Borok E, Xu AW, Janoschek R, Buch T, et al. Agouti-related peptideexpressing neurons are mandatory for feeding. Nat Neurosci 2005;8:1289-91. https://doi.org/10.1038/nn1548.

[12] Luquet S, Perez FA, Hnasko TS, Palmiter RD. NPY/AgRP neurons are essential for feeding in adult mice but can be ablated in neonates. Science 2005;310:683-5.

https://doi.org/10.1126/science.1115524.

[13] Willesen MG, Kristensen P, Rømer J. Co-Localization of Growth Hormone Secretagogue Receptor and NPY mRNA in the Arcuate Nucleus of the Rat. NEN 1999;70:306-16. https://doi.org/10.1159/000054491.

[14] Wang Q, Liu C, Uchida A, Chuang J-C, Walker A, Liu T, et al. Arcuate AgRP neurons mediate orexigenic and glucoregulatory actions of ghrelin. Molecular Metabolism 2014;3:64-72. https://doi.org/10.1016/j.molmet.2013.10.001.

[15] Wu C-S, Bongmba O, Yue J, Lee J, Lin L, Saito K, et al. Suppression of GHS-R in AgRP Neurons Mitigates Diet-Induced Obesity by Activating Thermogenesis. IJMS 2017;18:832. https://doi.org/10.3390/ijms18040832.

[16] Frankenfield DC. On heat, respiration, and calorimetry. Nutrition 2010;26:939-50. https://doi.org/10.1016/j.nut.2010.01.002.

[17] Tschöp M, Smiley DL, Heiman ML. Ghrelin induces adiposity in rodents. Nature 2000;407:908-13. https://doi.org/10.1038/35038090.

[18] Denis RGP, Joly-Amado A, Webber E, Langlet F, Schaeffer M, Padilla SL, et al. Palatability Can Drive Feeding Independent of AgRP Neurons. Cell Metab 2015;22:646-57. https://doi.org/10.1016/j.cmet.2015.07.011. 
[19] Jerlhag E. Systemic administration of ghrelin induces conditioned place preference and stimulates accumbal dopamine. Addiction Biology 2008;13:358-63. https://doi.org/10.1111/j.13691600.2008.00125.x.

[20] Jerlhag E, Egecioglu E, Dickson SL, Engel JA. Glutamatergic regulation of ghrelin-induced activation of the mesolimbic dopamine system: Mechanisms for ghrelin-induced reinforcement. Addiction Biology 2011;16:82-91. https://doi.org/10.1111/j.1369-1600.2010.00231.x.

[21] Cornejo MP, Barrile F, De Francesco PN, Portiansky EL, Reynaldo M, Perello M. Ghrelin Recruits Specific Subsets of Dopamine and GABA Neurons of Different Ventral Tegmental Area Sub-nuclei. Neuroscience 2018;392:107-20. https://doi.org/10.1016/j.neuroscience.2018.09.027.

[22] Naznin F, Toshinai K, Waise TMZ, Okada T, Sakoda H, Nakazato M. Restoration of metabolic inflammation-related ghrelin resistance by weight loss. Journal of Molecular Endocrinology 2018;60:109-18. https://doi.org/10.1530/JME-17-0192.

[23] Theander-Carrillo C. Ghrelin action in the brain controls adipocyte metabolism. Journal of Clinical Investigation 2006;116:1983-93. https://doi.org/10.1172/JCI25811.

[24] van den Pol AN, Yao Y, Fu L-Y, Foo K, Huang H, Coppari R, et al. Neuromedin B and Gastrin-Releasing Peptide Excite Arcuate Nucleus Neuropeptide Y Neurons in a Novel Transgenic Mouse Expressing Strong Renilla Green Fluorescent Protein in NPY Neurons. J Neurosci 2009;29:4622-39.

https://doi.org/10.1523/JNEUROSCI.3249-08.2009.

[25] Luquet S, Phillips CT, Palmiter RD. NPY/AgRP neurons are not essential for feeding responses to glucoprivation. Peptides 2007;28:214-25. https://doi.org/10.1016/j.peptides.2006.08.036.

[26] National Research Council (US) Committee for the Update of the Guide for the Care and Use of Laboratory Animals. Guide for the Care and Use of Laboratory Animals. 8th ed. Washington (DC): National Academies Press (US); 2011.

[27] Bilreiro C, Fernandes FF, Andrade L, Chavarrías C, Simões RV, Matos C, et al. Hyoscine butylbromide for bowel motion reduction in mouse abdominal MRI. ArXiv:200704282 [Physics] 2020.

[28] Lockie SH, Stark R, Mequinion M, Ch'ng S, Kong D, Spanswick DC, et al. Glucose Availability Predicts the Feeding Response to Ghrelin in Male Mice, an Effect Dependent on AMPK in AgRP Neurons. Endocrinology 2018;159:3605-14. https://doi.org/10.1210/en.2018-00536.

[29] Enriori PJ, Evans AE, Sinnayah P, Jobst EE, Tonelli-Lemos L, Billes SK, et al. Diet-induced obesity causes severe but reversible leptin resistance in arcuate melanocortin neurons. Cell Metab 2007;5:18194. https://doi.org/10.1016/j.cmet.2007.02.004.

[30] Kopin AS, Mathes WF, McBride EW, Nguyen M, Al-Haider W, Schmitz F, et al. The cholecystokinin-A receptor mediates inhibition of food intake yet is not essential for the maintenance of body weight. $J$ Clin 
Invest 1999;103:383-91. https://doi.org/10.1172/JCl4901.

[31] Navarro M, Lerma-Cabrera JM, Carvajal F, Lowery EG, Cubero I, Thiele TE. Assessment of voluntary ethanol consumption and the effects of a melanocortin (MC) receptor agonist on ethanol intake in mutant C57BL/6J mice lacking the MC-4 receptor. Alcohol Clin Exp Res 2011;35:1058-66. https://doi.org/10.1111/j.1530-0277.2011.01438.x.

[32] Cornejo MP, Castrogiovanni D, Schiöth HB, Reynaldo M, Marie J, Fehrentz J, et al. Growth hormone secretagogue receptor signalling affects high-fat intake independently of plasma levels of ghrelin and LEAP 2, in a 4-day binge eating model. J Neuroendocrinol 2019;31. https://doi.org/10.1111/jne.12785.

[33] Even PC, Nadkarni NA. Indirect calorimetry in laboratory mice and rats: principles, practical considerations, interpretation and perspectives. American Journal of Physiology-Regulatory, Integrative and Comparative Physiology 2012;303:R459-76. https://doi.org/10.1152/ajpregu.00137.2012.

[34] Weir JBDB. New methods for calculating metabolic rate with special reference to protein metabolism. J Physiol 1949;109:1-9. https://doi.org/10.1113/jphysiol.1949.sp004363.

[35] Cabral A, Suescun O, Zigman JM, Perello M. Ghrelin indirectly activates hypophysiotropic CRF neurons in rodents. PLoS ONE 2012;7:e31462. https://doi.org/10.1371/journal.pone.0031462.

[36] Cabral A, Cornejo MP, Fernandez G, De Francesco PN, Garcia-Romero G, Uriarte M, et al. Circulating Ghrelin Acts on GABA Neurons of the Area Postrema and Mediates Gastric Emptying in Male Mice. Endocrinology 2017;158:1436-49. https://doi.org/10.1210/en.2016-1815.

[37] Shoji E, Okumura T, Onodera S, Takahashi N, Harada K, Kohgo Y. Gastric emptying in OLETF rats not expressing CCK-A receptor gene. Dig Dis Sci 1997;42:915-9. https://doi.org/10.1023/a:1018860313674.

[38] Paxinos G, Franklin KBJ. The Mouse Brain in Stereotaxic Coordinates 2001.

[39] Murai A, Iwamura K, Takada M, Ogawa K, Usui T, Okumura J. Control of postprandial hyperglycaemia by galactosyl maltobionolactone and its novel anti-amylase effect in mice. Life Sci 2002;71:1405-15. https://doi.org/10.1016/s0024-3205(02)01844-1.

[40] Page LC, Gastaldelli A, Gray SM, D'Alessio DA, Tong J. Interaction of GLP-1 and Ghrelin on Glucose Tolerance in Healthy Humans. Diabetes 2018;67:1976-85. https://doi.org/10.2337/db18-0451.

[41] Caixás A, Bashore C, Nash W, Pi-Sunyer F, Laferrère B. Insulin, unlike food intake, does not suppress ghrelin in human subjects. J Clin Endocrinol Metab 2002;87:1902.

https://doi.org/10.1210/jcem.87.4.8538.

[42] Wells AS, Read NW, Uvnas-Moberg K, Alster P. Influences of fat and carbohydrate on postprandial sleepiness, mood, and hormones. Physiol Behav 1997;61:679-86. https://doi.org/10.1016/s00319384(96)00519-7. 
[43] Kobelt P, Tebbe JJ, Tjandra I, Stengel A, Bae H-G, Andresen V, et al. CCK inhibits the orexigenic effect of peripheral ghrelin. Am J Physiol Regul Integr Comp Physiol 2005;288:R751-758. https://doi.org/10.1152/ajpregu.00094.2004.

[44] Phillips RJ, Powley TL. Gastric volume rather than nutrient content inhibits food intake. Am J Physiol 1996;271:R766-769. https://doi.org/10.1152/ajpregu.1996.271.3.R766.

[45] Powley TL, Phillips RJ. Gastric satiation is volumetric, intestinal satiation is nutritive. Physiol Behav 2004;82:69-74. https://doi.org/10.1016/j.physbeh.2004.04.037.

[46] Asakawa A, Inui A, Kaga T, Yuzuriha H, Nagata T, Ueno N, et al. Ghrelin is an appetite-stimulatory signal from stomach with structural resemblance to motilin. Gastroenterology 2001;120:337-45. https://doi.org/10.1053/gast.2001.22158.

[47] Stacher G, Bergmann H, Havlik E, Schmierer G, Schneider C. Effects of oral cyclotropium bromide, hyoscine N-butylbromide and placebo on gastric emptying and antral motor activity in healthy man. Gut 1984;25:485-90. https://doi.org/10.1136/gut.25.5.485.

[48] Nakazato M, Murakami N, Date Y, Kojima M, Matsuo H, Kangawa K, et al. A role for ghrelin in the central regulation of feeding. Nature 2001;409:194-8. https://doi.org/10.1038/35051587.

[49] Kim ER, Tong Q. Oxygen Consumption Rate and Energy Expenditure in Mice: Indirect Calorimetry. In: Wu J, editor. Thermogenic Fat: Methods and Protocols, New York, NY: Springer; 2017, p. 135-43. https://doi.org/10.1007/978-1-4939-6820-6_13.

[50] Cabral A, Fernandez G, Tolosa MJ, Rey Moggia Á, Calfa G, De Francesco PN, et al. Fasting induces remodeling of the orexigenic projections from the arcuate nucleus to the hypothalamic paraventricular nucleus, in a growth hormone secretagogue receptor-dependent manner. Molecular Metabolism 2020;32:69-84. https://doi.org/10.1016/j.molmet.2019.11.014.

[51] Chuang J-C, Perello M, Sakata I, Osborne-Lawrence S, Savitt JM, Lutter M, et al. Ghrelin mediates stress-induced food-reward behavior in mice. J Clin Invest 2011;121:2684-92. https://doi.org/10.1172/JCl57660.

[52] Westerterp KR. Control of energy expenditure in humans. Eur J Clin Nutr 2017;71:340-4. https://doi.org/10.1038/ejcn.2016.237.

[53] Tsubone T, Masaki T, Katsuragi I, Tanaka K, Kakuma T, Yoshimatsu H. Ghrelin regulates adiposity in white adipose tissue and UCP1 mRNA expression in brown adipose tissue in mice. Regul Pept 2005;130:97-103. https://doi.org/10.1016/j.regpep.2005.04.004.

[54] Yasuda T, Masaki T, Kakuma T, Yoshimatsu H. Centrally administered ghrelin suppresses sympathetic nerve activity in brown adipose tissue of rats. Neuroscience Letters 2003;349:75-8. https://doi.org/10.1016/S0304-3940(03)00789-4. 
[55] Abtahi S, Mirza A, Howell E, Currie PJ. Ghrelin enhances food intake and carbohydrate oxidation in a nitric oxide dependent manner. Gen Comp Endocrinol 2017;250:9-14.

https://doi.org/10.1016/j.ygcen.2017.05.017.

[56] Kohno D, Gao H-Z, Muroya S, Kikuyama S, Yada T. Ghrelin Directly Interacts With Neuropeptide-YContaining Neurons in the Rat Arcuate Nucleus 2003;52:9.

[57] Yang Y, Atasoy D, Su HH, Sternson SM. Hunger States Switch a Flip-Flop Memory Circuit via a Synaptic AMPK-Dependent Positive Feedback Loop. Cell 2011;146:992-1003.

https://doi.org/10.1016/j.cell.2011.07.039.

[58] Chen HY, Trumbauer ME, Chen AS, Weingarth DT, Adams JR, Frazier EG, et al. Orexigenic Action of Peripheral Ghrelin Is Mediated by Neuropeptide $Y$ and Agouti-Related Protein. Endocrinology 2004;145:2607-12. https://doi.org/10.1210/en.2003-1596.

[59] Chen Y, Lin Y-C, Zimmerman CA, Essner RA, Knight ZA. Hunger neurons drive feeding through a sustained, positive reinforcement signal. ELife 2016;5:e18640. https://doi.org/10.7554/eLife.18640.

[60] Nakajima K, Cui Z, Li C, Meister J, Cui Y, Fu O, et al. Gs-coupled GPCR signalling in AgRP neurons triggers sustained increase in food intake. Nat Commun 2016;7. https://doi.org/10.1038/ncomms10268.

[61] Semjonous NM, Smith KL, Parkinson JRC, Gunner DJL, Liu Y-L, Murphy KG, et al. Coordinated changes in energy intake and expenditure following hypothalamic administration of neuropeptides involved in energy balance. Int J Obes (Lond) 2009;33:775-85. https://doi.org/10.1038/ijo.2009.96.

[62] Atasoy D, Betley JN, Su HH, Sternson SM. Deconstruction of a neural circuit for hunger. Nature 2012;488:172-7. https://doi.org/10.1038/nature11270.

[63] Krashes MJ, Shah BP, Koda S, Lowell BB. Rapid versus Delayed Stimulation of Feeding by the Endogenously Released AgRP Neuron Mediators GABA, NPY, and AgRP. Cell Metabolism 2013;18:58895. https://doi.org/10.1016/j.cmet.2013.09.009.

[64] Chen Y, Essner RA, Kosar S, Miller OH, Lin Y-C, Mesgarzadeh S, et al. Sustained NPY signaling enables AgRP neurons to drive feeding. ELife 2019;8:e46348. https://doi.org/10.7554/eLife.46348.

[65] Pomeroy AR, Rand MJ. Anticholinergic effects and passage through the intestinal wall of Nbutylhyoscine bromide. Journal of Pharmacy and Pharmacology 1969;21:180-7. https://doi.org/10.1111/j.2042-7158.1969.tb08224.x.

[66] Bai L, Mesgarzadeh S, Ramesh KS, Huey EL, Liu Y, Gray LA, et al. Genetic Identification of Vagal Sensory Neurons That Control Feeding. Cell 2019;179:1129-1143.e23. https://doi.org/10.1016/j.cell.2019.10.031. 
[67] Kohno D, Nakata M, Maekawa F, Fujiwara K, Maejima Y, Kuramochi M, et al. Leptin suppresses ghrelin-induced activation of neuropeptide $Y$ neurons in the arcuate nucleus via phosphatidylinositol 3kinase- and phosphodiesterase 3-mediated pathway. Endocrinology 2007;148:2251-63. https://doi.org/10.1210/en.2006-1240.

[68] Perello M, Scott MM, Sakata I, Lee CE, Chuang J-C, Osborne-Lawrence S, et al. Functional implications of limited leptin receptor and ghrelin receptor coexpression in the brain. Journal of Comparative Neurology 2012;520:281-94. https://doi.org/10.1002/cne.22690.

[69] Burdakov D, Ashcroft FM. Cholecystokinin tunes firing of an electrically distinct subset of arcuate nucleus neurons by activating A-Type potassium channels. J Neurosci 2002;22:6380-7. https://doi.org/20026685.

[70] Su Z, Alhadeff AL, Betley JN. Nutritive, Post-ingestive Signals Are the Primary Regulators of AgRP Neuron Activity. Cell Rep 2017;21:2724-36. https://doi.org/10.1016/j.celrep.2017.11.036.

[71] Andreoli MF, De Francesco PN, Perello M. Gastrointestinal Hormones Controlling Energy Homeostasis and Their Potential Role in Obesity. In: Nillni EA, editor. Textbook of Energy Balance, Neuropeptide Hormones, and Neuroendocrine Function, Cham: Springer International Publishing; 2018, p. 183-203. https://doi.org/10.1007/978-3-319-89506-2_7.

\section{Figures}

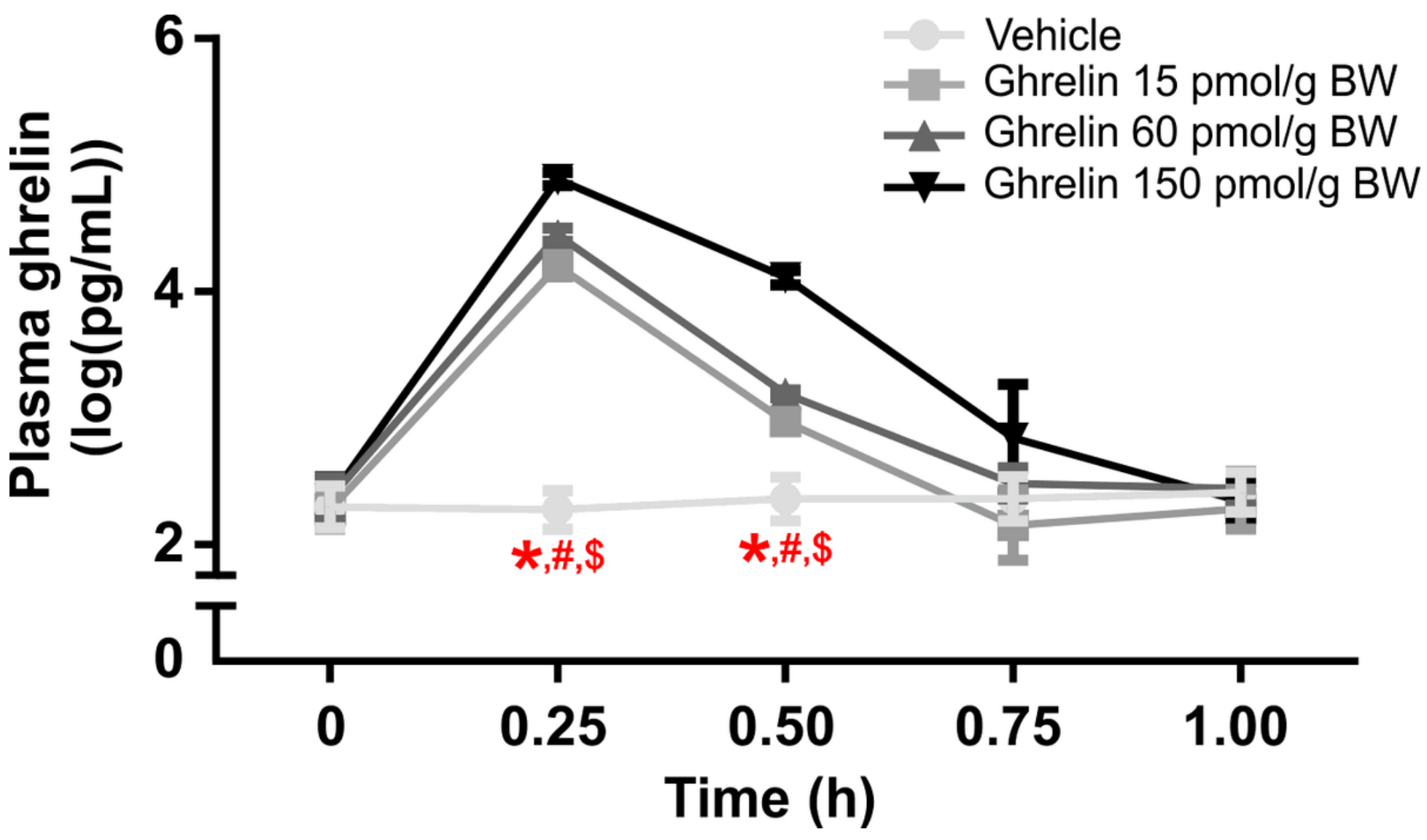


Figure 1

Plasma ghrelin levels after IP injections of different doses of ghrelin. The figure shows the time course of plasma ghrelin levels after IP administration of different doses of ghrelin. *, $\#$ and $\$ ; P<0.05$ vs ghrelin 15 , 60 and $150 \mathrm{pmol} / \mathrm{g}$, respectively. Two-way ANOVA followed by Dunnett's multiple comparisons test.

a

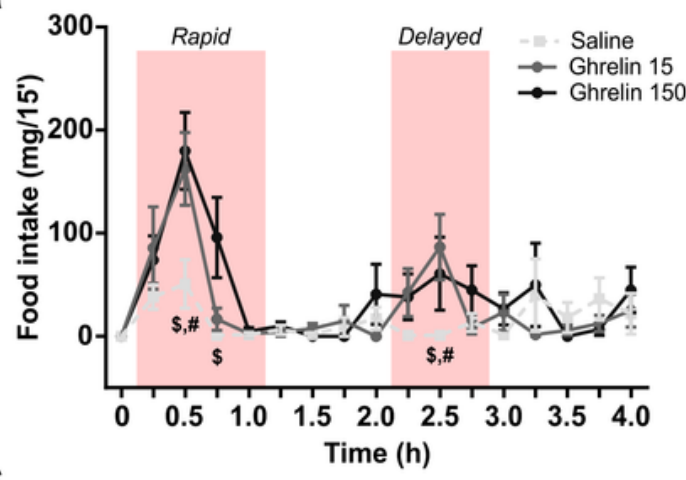

C

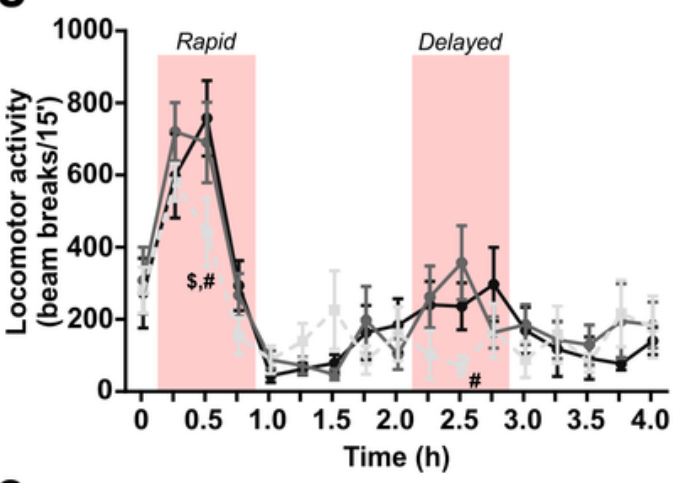

e

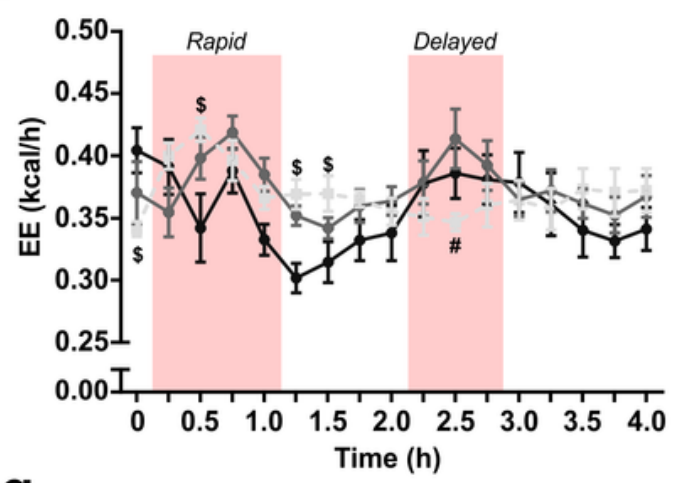

g

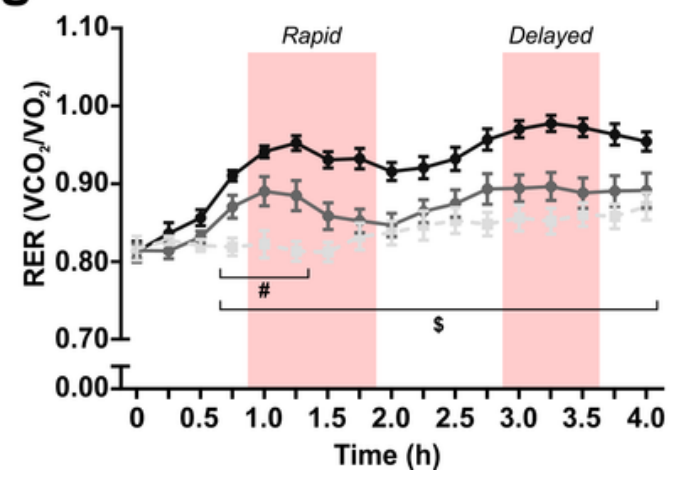

b

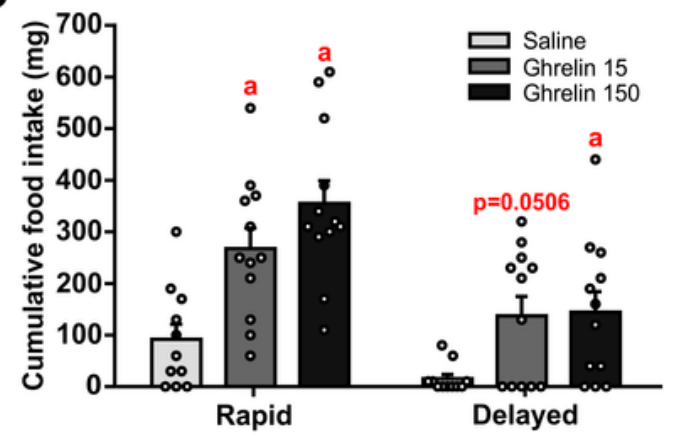

d

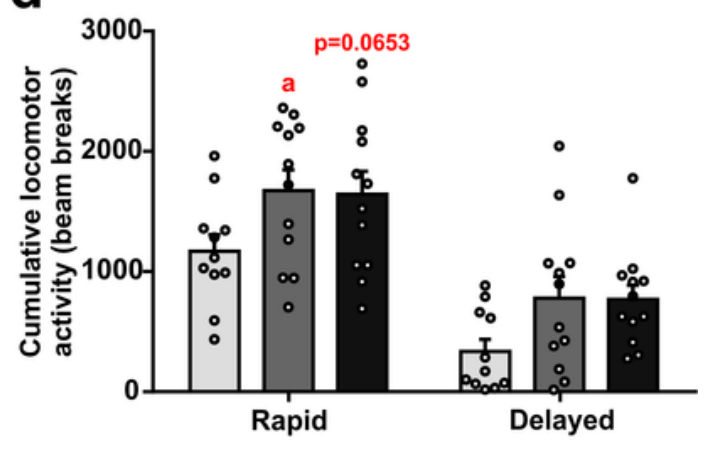

f

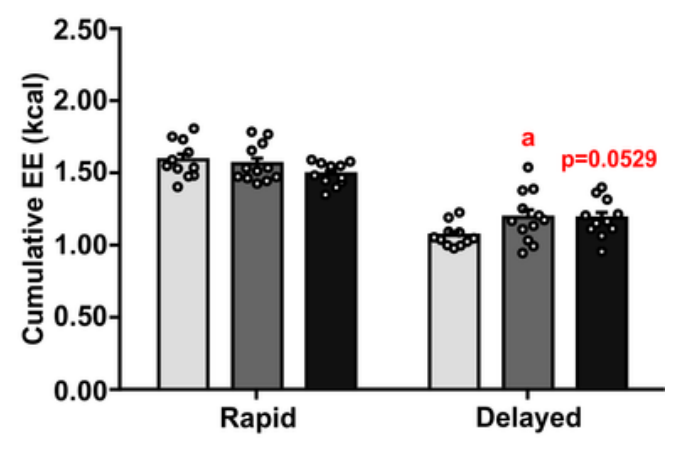

h

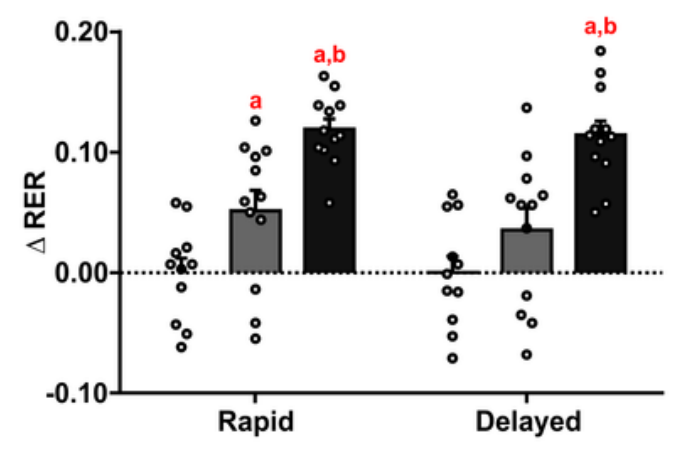

Figure 2 
Ghrelin treatment induces a rapid and a delayed effect on food intake, EE and the RER. a, c, e and g show the 0.25 h-period food intake (a), locomotor activity (c), EE (e) and RER (g) of 15 and $150 \mathrm{pmol} / \mathrm{g} \mathrm{BW}$ of ghrelin- and saline-treated mice. Pink rectangles indicate the rapid and delayed time periods used to calculate the cumulative values showed in $b, d$, $f$ and $h$. Repeated measures (RM) two-way ANOVA followed by a Dunnett's multiple comparisons test were performed ( $\$, P<0.05 \mathrm{vs} 150 \mathrm{pmol} / \mathrm{g}$ BW and \#, $P<0.05$ vs $15 \mathrm{pmol} / \mathrm{g}$ BW of ghrelin). $b, d, f$ and h show the quantitative analysis of the cumulative food intake (b), locomotor activity (d) and EE (f) and the changes in the RER between ghrelin- and salinetreated mice $(h)$ in the rapid and delayed time periods. White-filled circles represent individual values. RM two-way ANOVA followed by a Dunnett's and a Tukey's multiple comparisons test were performed $(a$, $P<0.05$ vs saline and $b, p<0.05$ vs $15 \mathrm{pmol} / \mathrm{g}$ BW of ghrelin). 
a

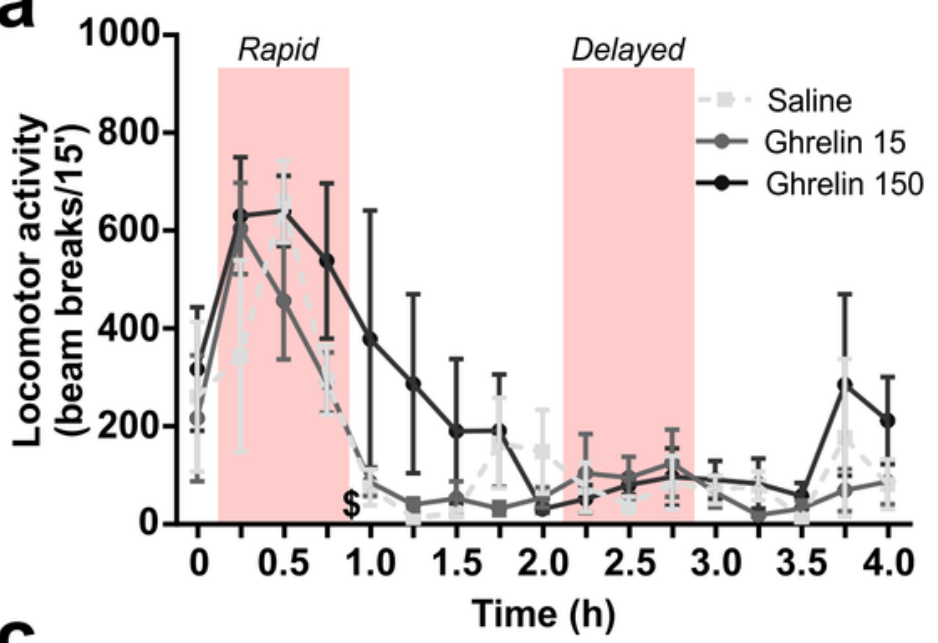

C

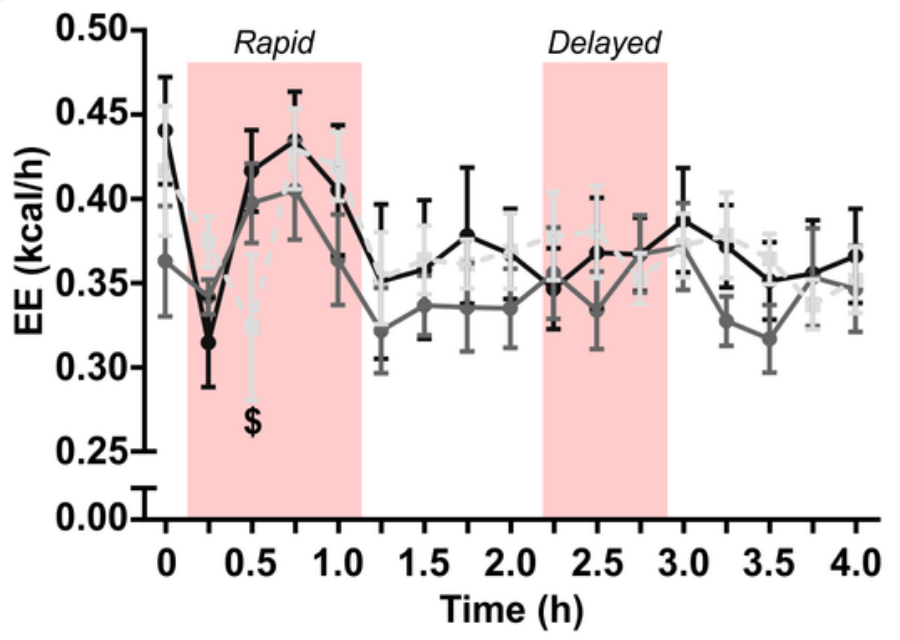

e

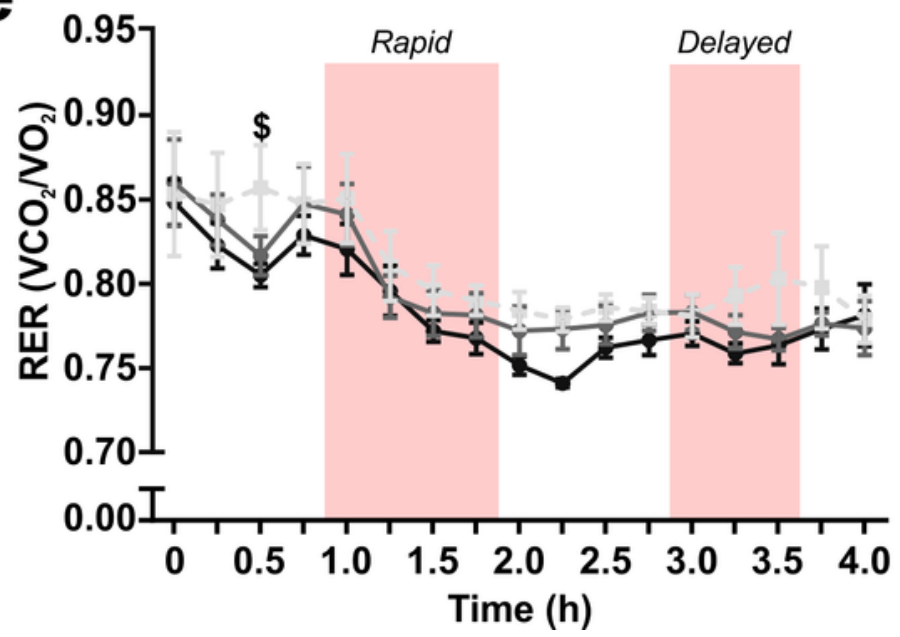

b
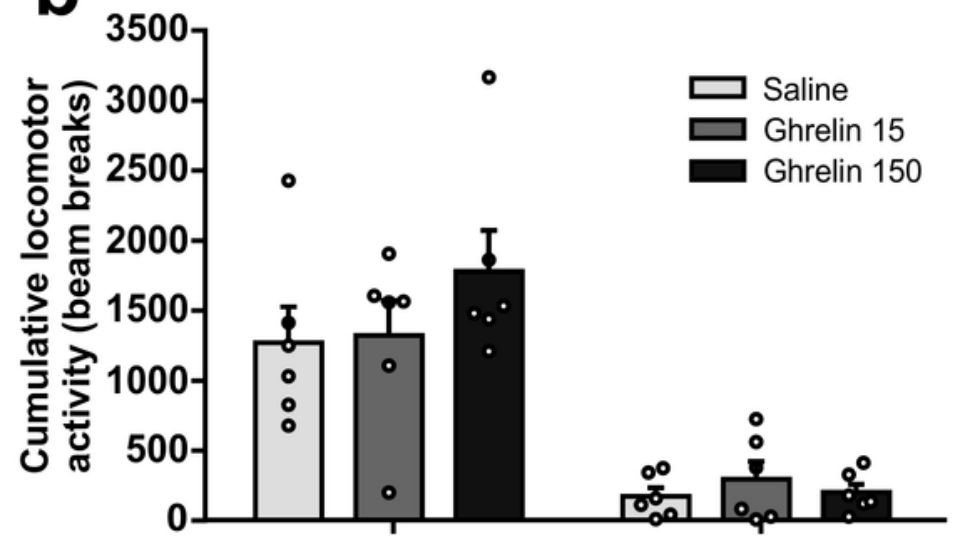

Rapid

Delayed
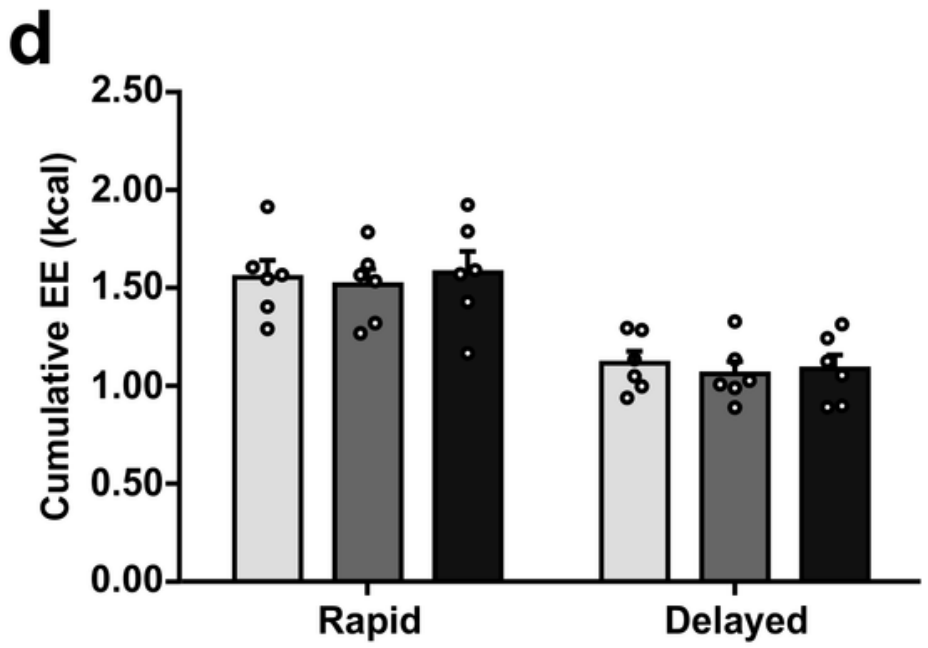

f

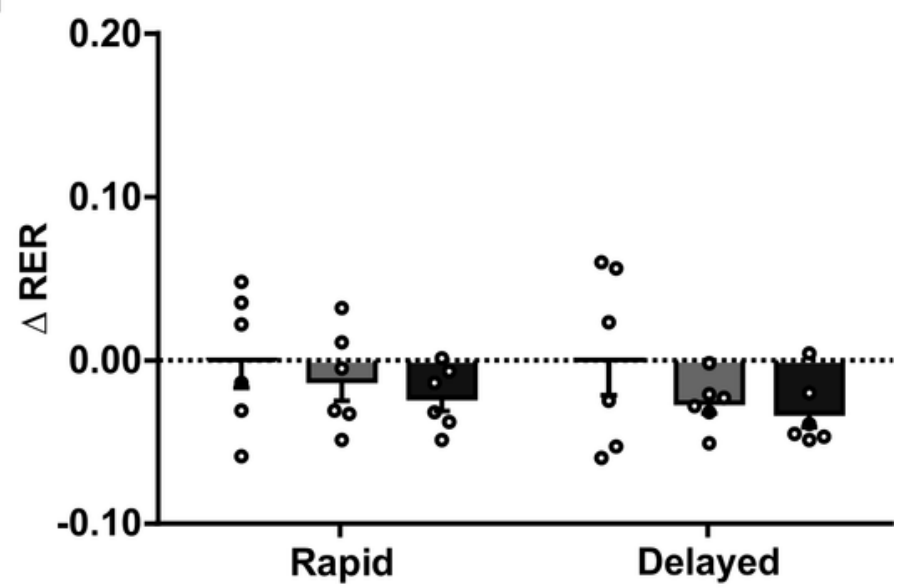

Figure 3

Ghrelin treatment does not affect EE and the RER in mice not allowed to eat after treatment. a, c and e show the 0.25 h-period locomotor activity (a), EE (c) and the RER (e) of the $150 \mathrm{pmol} / \mathrm{g} \mathrm{BW}$ and 15 $\mathrm{pmol} / \mathrm{g}$ BW of ghrelin- and saline-treated mice. Pink rectangles indicate the rapid and delayed time periods used to calculate the cumulative values showed in $b, d$ and $f$. RM two-way ANOVA followed by Dunnett's multiple comparisons test were performed (\$, $P<0.05$ vs $150 \mathrm{pmol} / \mathrm{g}$ BW of ghrelin). $b, d$ and $f$ 
show the quantitative analysis of the cumulative locomotor activity (b) and EE (d) and the changes in the RER (f) between ghrelin- and saline-treated mice in the rapid and delayed time periods. White-filled circles represent individual values.
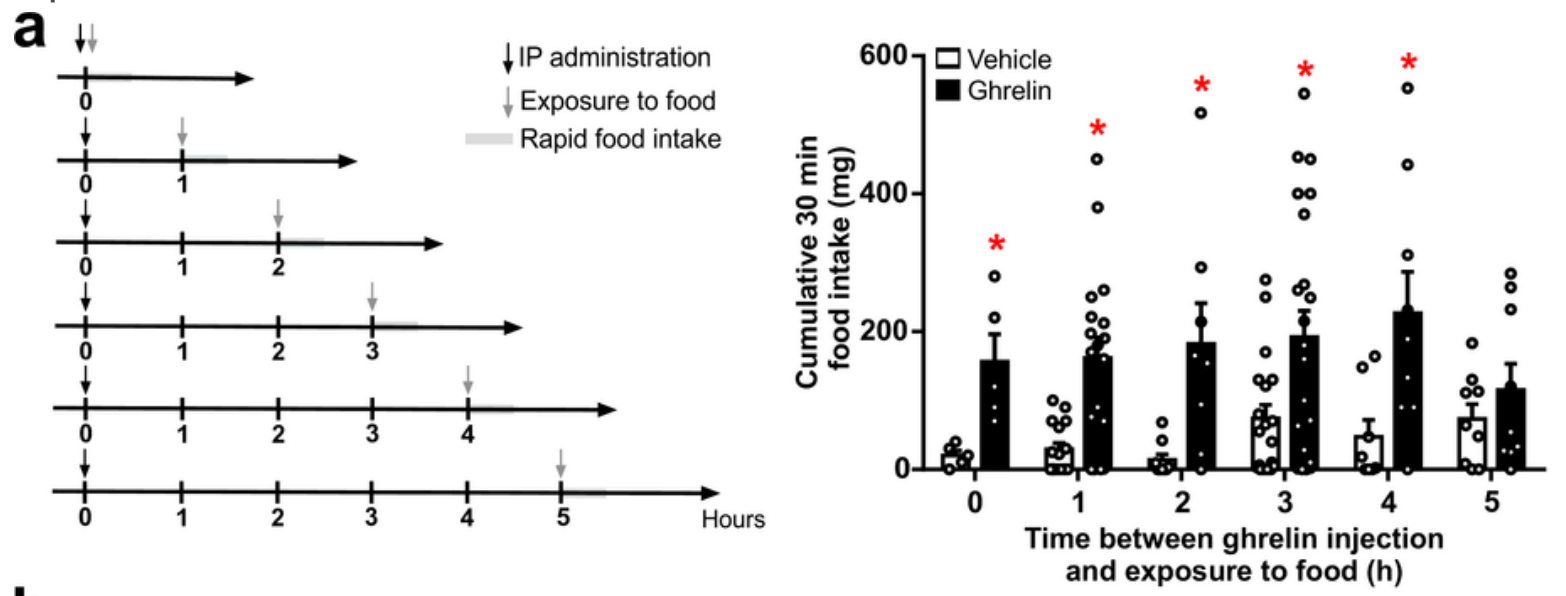

b
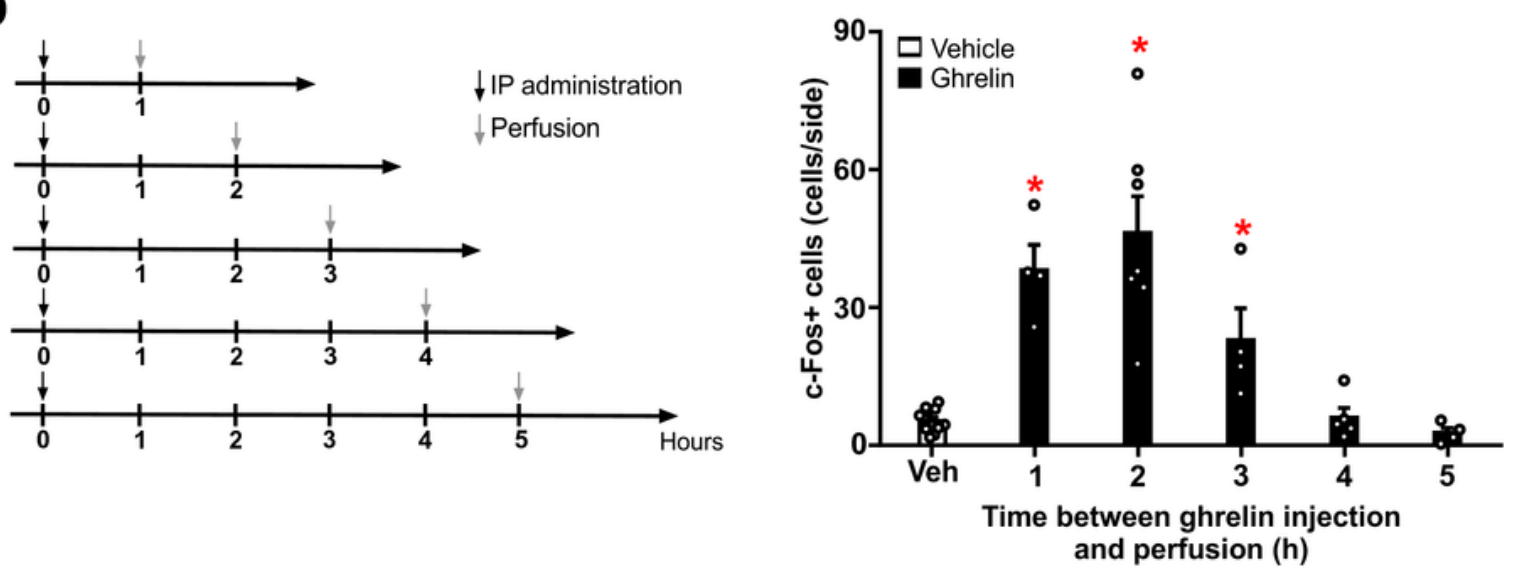

C

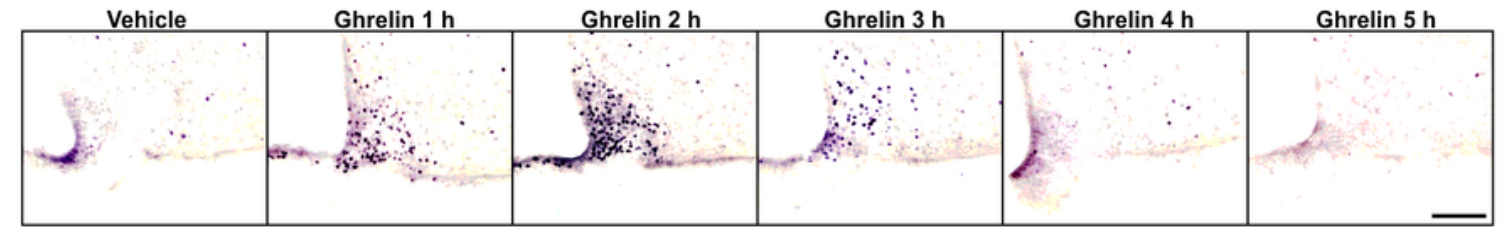

d

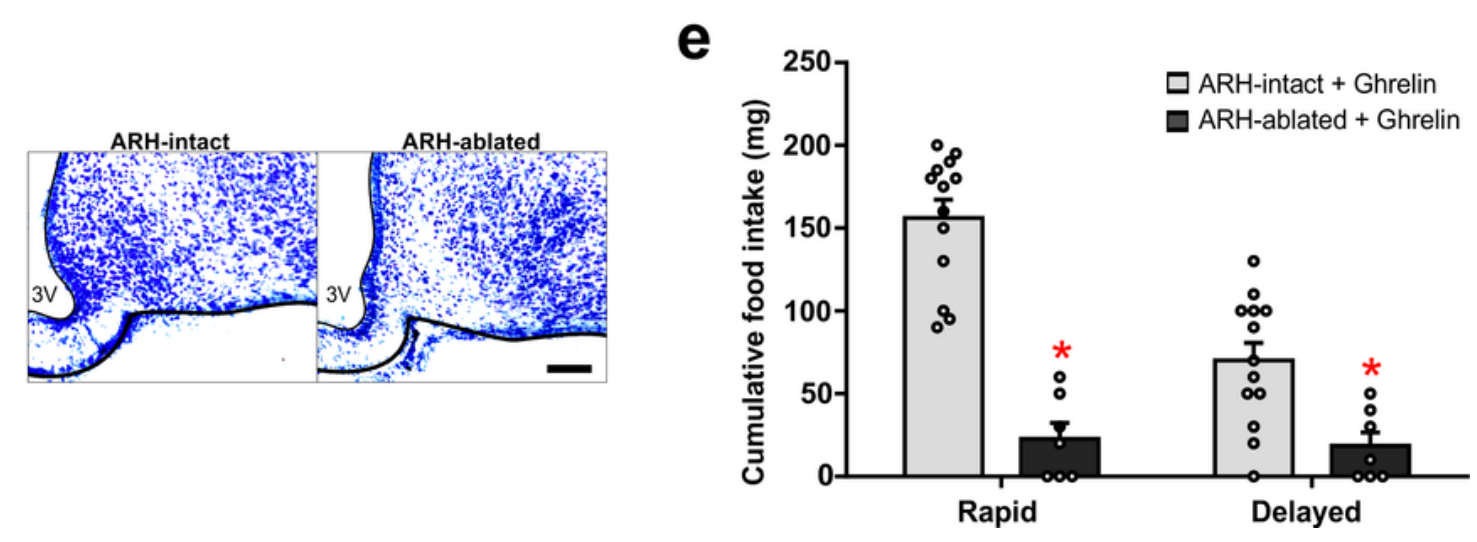

Figure 4

Rapid and delayed effects of ghrelin treatment on food intake involve the $\mathrm{ARH}$. a shows a schematic representation of the experimental design (left timeline) and the quantitative analysis of the $0.5 \mathrm{~h}$ 
cumulative food intake (right bar graph) of mice IP administered with vehicle or ghrelin and exposed to food at different timepoints. White-filled circles represent individual values. Two-way ANOVA followed by Sidak's multiple comparisons test were performed ( ${ }^{*}, \mathrm{P}<0.05$ vs vehicle at each time). $\mathrm{b}$ shows a schematic representation of the experimental design (left timeline) and the quantitative analysis (right bar graph) of the number of c-Fos+ cells in the ARH of mice IP injected with vehicle or ghrelin and perfused at different timepoints. White-filled circles represent individual values. Two-way ANOVA followed by Sidak's multiple comparisons test were performed $\left({ }^{*}, \mathrm{P}<0.05\right.$ vs vehicle at each time). $c$ shows representative photomicrographs of the coronal sections of the ARH of mice IP administered with ghrelin and sacrificed at different timepoints that were subjected to an anti-c-Fos immunostaining (and quantified in B). Scale bar: $100 \mu \mathrm{m}$. d shows representative photomicrographs of a Nissl staining performed in coronal brain sections of ARH-intact (left) and ARH-ablated (right) mice. Scale bar: $100 \mu \mathrm{m}$. e shows the quantitative analysis of cumulative food intake in the rapid and delayed time periods of ARHintact and ARH-ablated mice IP injected with ghrelin. White-filled circles represent individual values. Twoway ANOVA followed by Sidak's multiple comparisons test were performed ( ${ }^{*}, p<0.05$ vs ARH-intact). 
a
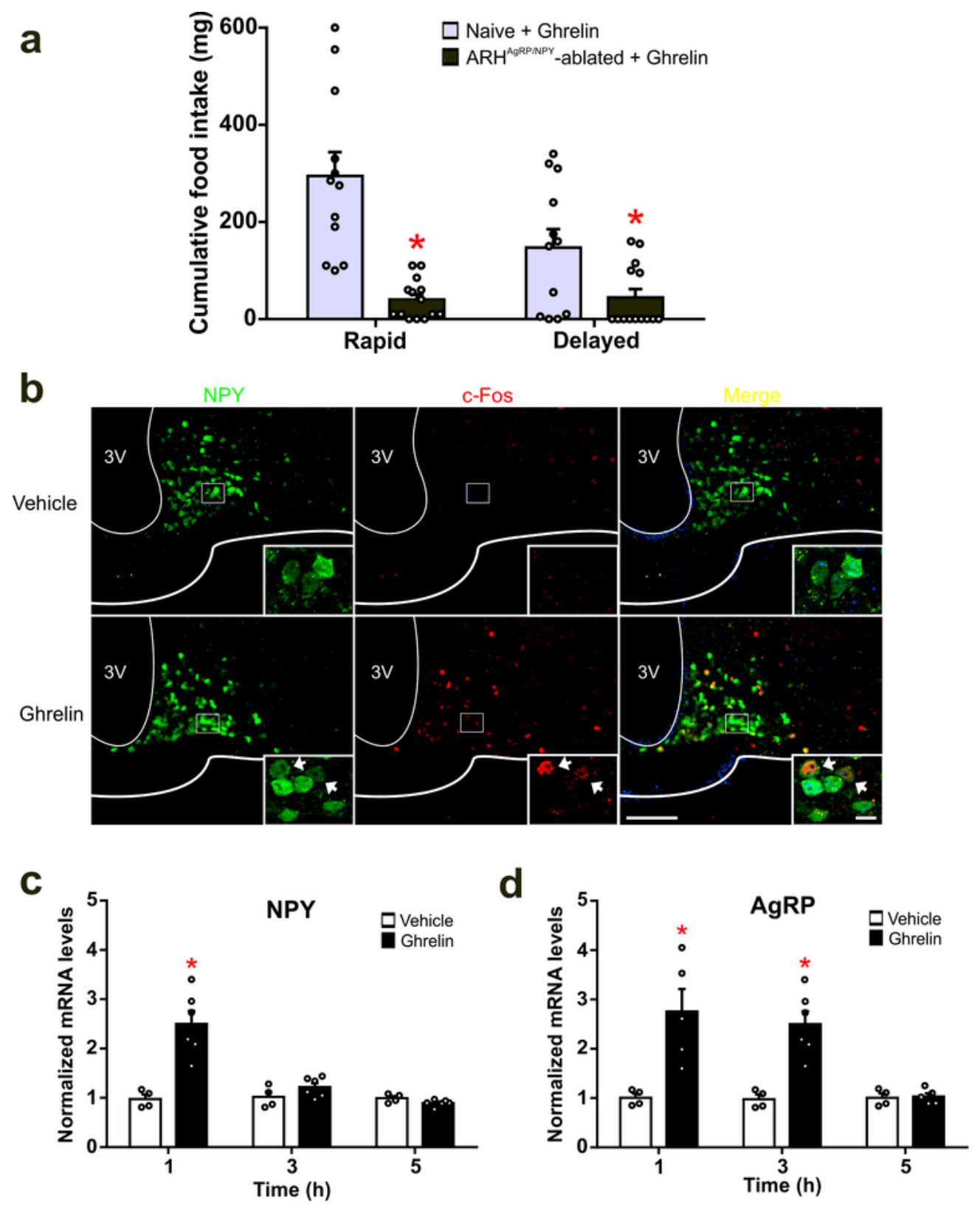

e
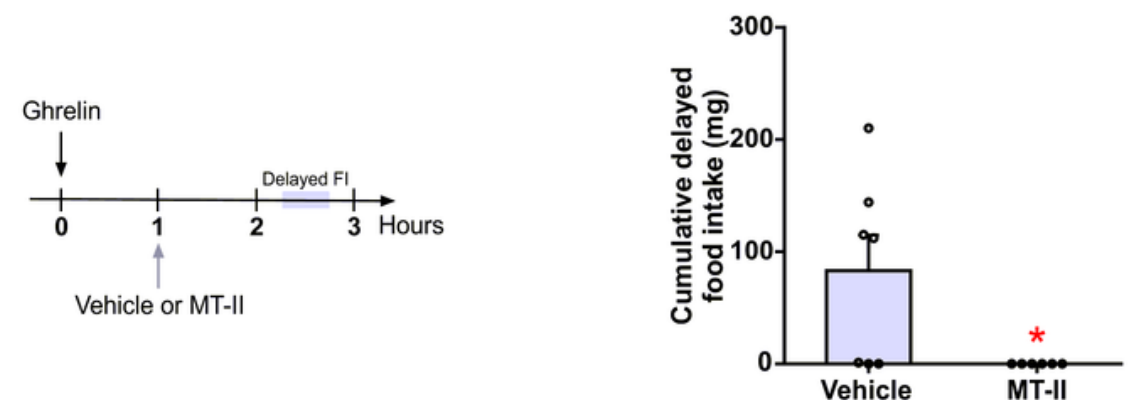

\section{Figure 5}

Rapid and delayed orexigenic effects of ghrelin involve ARHAgRP/NPY neurons. a shows the quantitative analysis of cumulative food intake in the rapid and delayed time periods of naïve and ARHAgRP/NPY neurons-ablated mice IP administered with ghrelin. White-filled circles represent individual values. Twoway ANOVA followed by Sidak's multiple comparisons test were performed $\left({ }^{*}, \mathrm{P}<0.05\right.$ vs vehicle at each time). b displays representative photomicrographs of the immunostaining against c-Fos (red signal) in 
brain sections containing the ARH of NPY-GFP mice (green signal). High magnification images show the areas delimited with a rectangle in the low magnification micrographs and arrows point to c-Fos+ GFP expressing cells. Scale bars: $100 \mu \mathrm{m}$ low and $10 \mu \mathrm{m}$ high magnification images. $\mathrm{c}$ and $\mathrm{d}$ show the quantitative analysis of the mRNA levels of NPY (c) and AgRP (d) in the ARH of mice IP injected with vehicle or ghrelin and sacrificed at 1, 3 and $5 \mathrm{~h}$ after treatment. White-filled circles represent individual values. Two-way ANOVA followed by Bonferroni's multiple comparisons test were performed ( ${ }^{*}, \mathrm{P}<0.05$ vs vehicle at each time). e shows a schematic representation of the experimental design (left timeline) and the quantitative analysis of the cumulative food intake (right bar graph) in the delayed time period of mice IP administered with ghrelin and ICV injected with vehicle (aCSF) or MT-II. White-filled circles represent individual values. Mann-Whitney test was performed $(*, P<0.05)$.

a
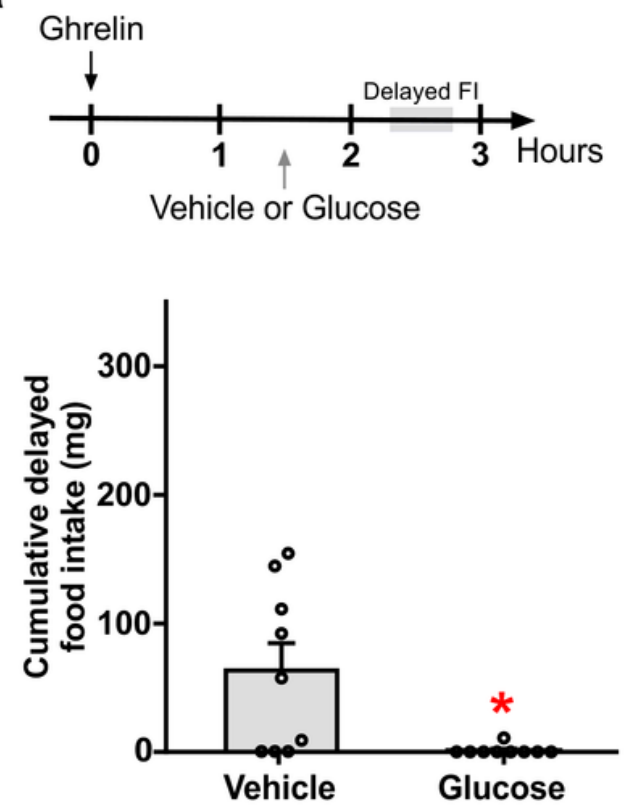

C
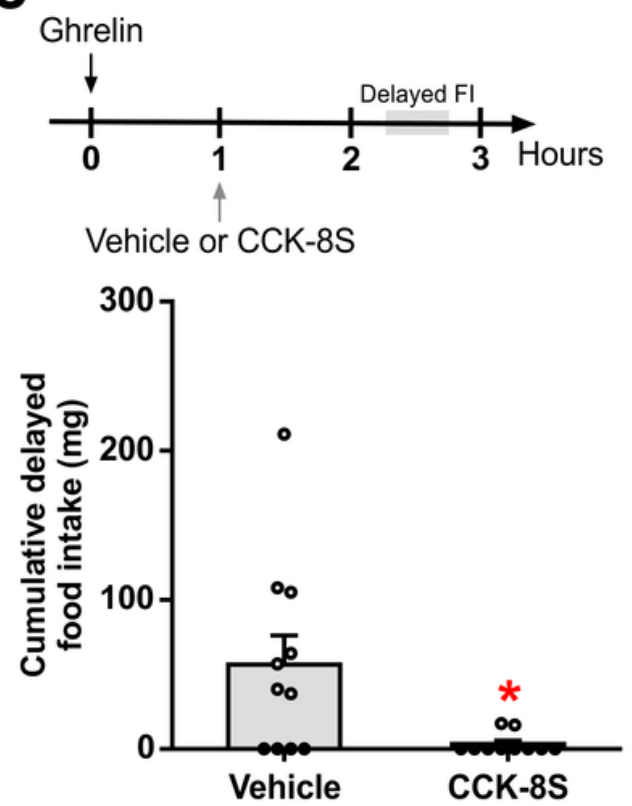

b

Ghrelin

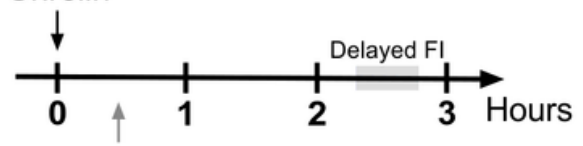

Vehicle or 2-D-Glucose

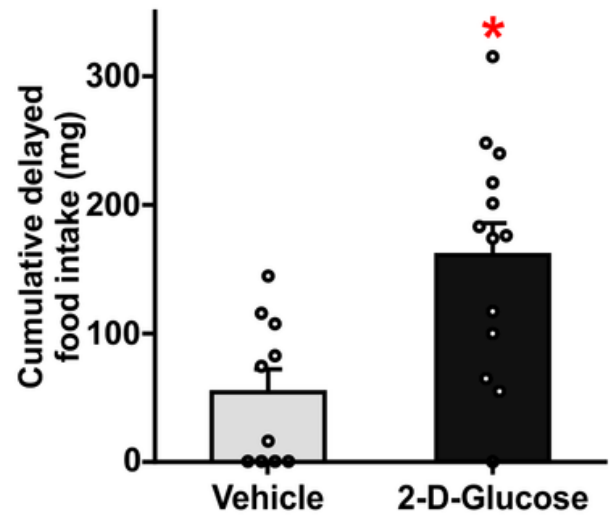

e

Ghrelin

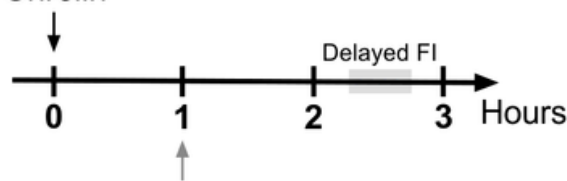

Vehicle or Hyoscine butyl-bromide

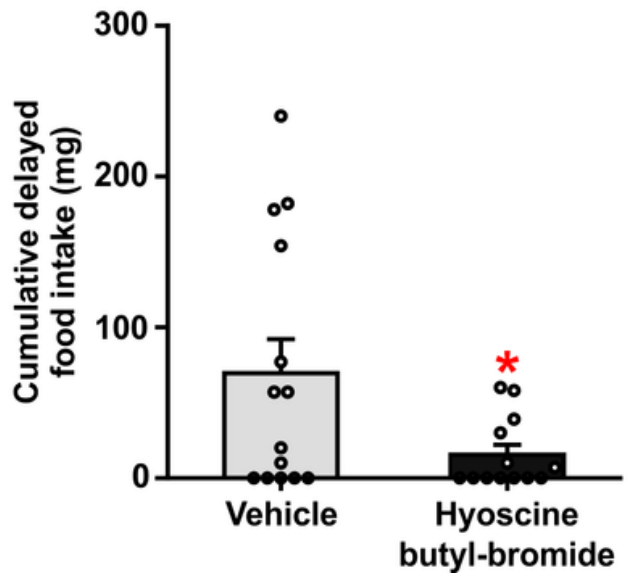

Ghrelin

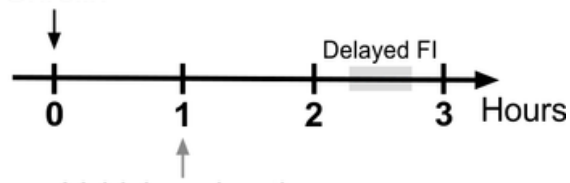

Vehicle or Leptin

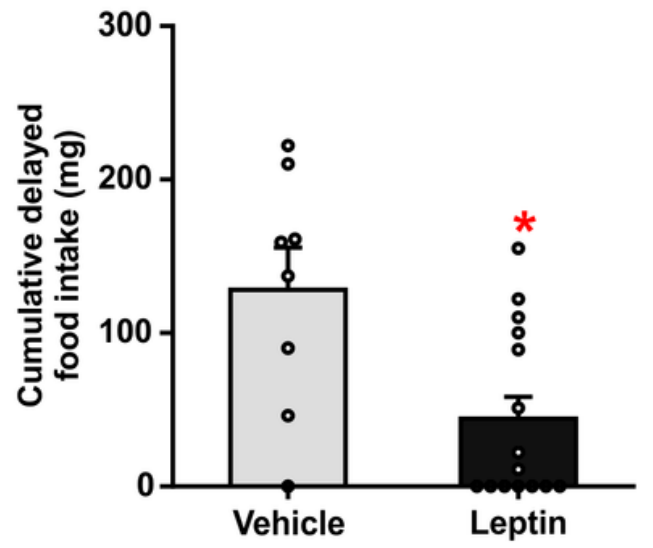




\section{Figure 6}

The delayed orexigenic effect of ghrelin is counteracted by satiety signals. a-e displays a schematic representation of the experimental design (upper timelines) and the quantitative analysis of the cumulative food intake (bottom bar graphs) in the delayed time period of mice IP injected with ghrelin and then IP administered with either vehicle, glucose (a), 2-deoxi-glucose (b), CCK-8S (c), hyoscine butylbromide (d) or leptin (e). Mann-Whitney, unpaired t-test with Welch's correction and unpaired t test were performed to analyze Glucose and CCK-8S, hyoscine butyl-bromide and 2-deoxi-glucose and leptin data sets, respectively $(*, \mathrm{P}<0.05)$.

a

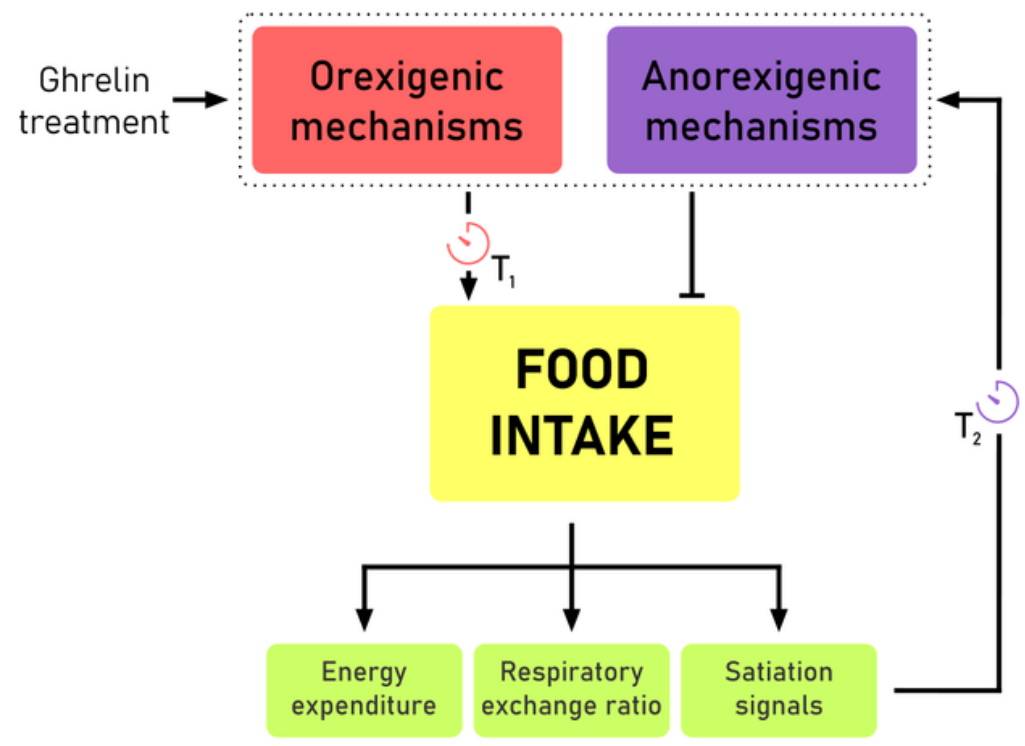

b

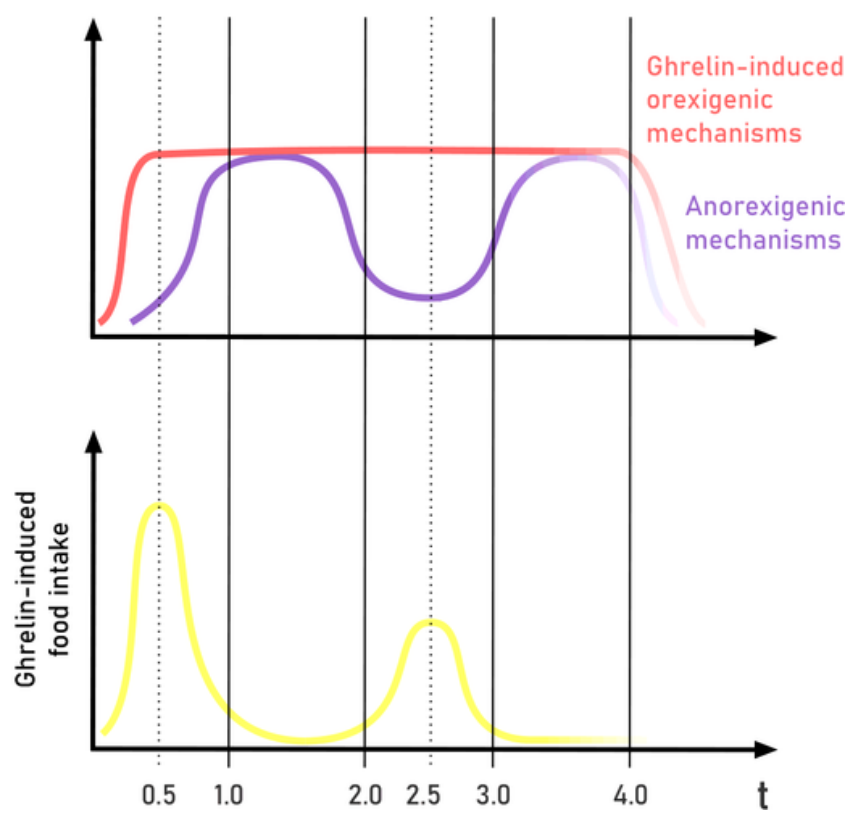

\section{Figure 7}

Heuristic hypothetical model to explain the rapid and delayed effects of ghrelin treatment on food intake. a depicts the proposed model: systemically injected ghrelin potently activates orexigenic mechanisms, which involve ARHAgRP/NPY neurons, that rapidly drive food intake. Ghrelin-induced food intake affects $\mathrm{EE}$ and the RER and also up-regulates a number of satiation signals that, in turn, recruit anorexigenic mechanisms that counteract ghrelin-induced orexigenic mechanisms. Thus, ghrelin-induced food intake is transiently neutralized. Plasma ghrelin levels increase for less than $1 \mathrm{~h}$, but ghrelin-triggered orexigenic mechanisms persist for several hours after treatment (represented as a pink timer, in which T1 is a specific time interval). The duration of ghrelin-induced orexigenic mechanisms seems to be longer than duration of food intake-induced anorexigenic mechanisms (represented as a purple timer, in which T2 is another specific time interval, smaller than T1) and, consequently, a delayed effect of ghrelin-induced food intake is observed. $b$ illustrates a theoretical time-course response for ghrelin-induced orexigenic mechanisms and food intake-induced anorexigenic mechanisms (upper) and the resulting ghrelininduced food intake (bottom) after a single bolus of ghrelin. 